
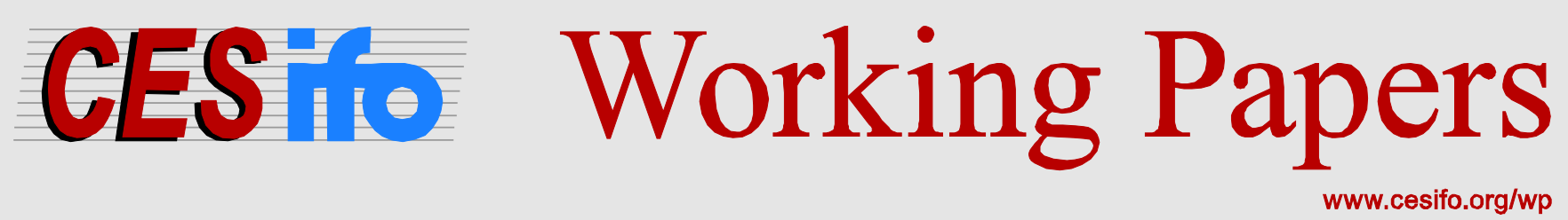

\title{
The Cost of Decentralization: Linguistic Polarization and the Provision of Education
}

\author{
Francesco Cinnirella \\ Ruth M. Schueler
}

CESIFO WORKING PAPER NO. 5894

CATEGORY 5: ECONOMICS OF EDUCATION

MAY 2016

An electronic version of the paper may be downloaded

- from the SSRN website: Www.SSRN.com

- from the RePEc website: $\quad$ www.RePEc.org

- from the CESifo website: www.CESifo-group.org/wp 


\title{
The Cost of Decentralization: Linguistic Polarization and the Provision of Education
}

\begin{abstract}
In this paper we argue that different preferences in a decentralized system lead to under provision of public goods. We analyze the provision of public primary education in nineteenthcentury Prussia which was characterized by a linguistically polarized society and a decentralized education system. Using unique county-level data on education spending we show that linguistic polarization has a negative impact on local spending. Instrumental variable estimates using distance to the eastern border suggest that the relationship can be causally interpreted. Exploiting a reform of education spending, we show that centralization increases the provision of primary education relatively more in linguistically polarized counties.
\end{abstract}

JEL-Codes: H410, H750, I220, N130, N330.

Keywords: education, public goods, polarization, decentralization, centralization, Prussia.

\author{
Francesco Cinnirella* \\ Ifo Institute - Leibniz Institute for \\ Economic Research \\ at the University of Munich \\ Poschingerstrasse 5 \\ Germany-81679 Munich \\ cinnirella@ifo.de
}

\author{
Ruth M. Schueler \\ Ifo Institute - Leibniz Institute for \\ Economic Research \\ at the University of Munich \\ Poschingerstrasse 5 \\ Germany - 81679 Munich \\ schueler@ifo.de
}

*corresponding author

May 10, 2016

We are grateful to Sascha O. Becker, Pawel Bukowski, Vicky Fouka, Eric Hanushek, Erik Hornung, Sibylle Lehmann-Hasemeyer, Ralf Meisenzahl, Stelios Michalopoulos, Luigi Pascali, Rita Peto, Alfred Reckendrees, Guido Schwerdt, Jochen Streb, Justin Tumlinson, Michelangelo Vasta, Simon Wiederhold, Ludger Woessmann, Niko Wolf, and participants at the European Historical Economics Society (EHES) Summer School in Berlin, the First German Economic History Congress in Münster, the Annual Conference of the Association for the Study of Religion, Economics and Culture (ASREC) in Boston, the 11th Conference of the European Historical Economics Society (EHES) in Pisa and seminar participants at the University of Siena, Hohenheim, Mannheim, and at the Ifo Institute for their comments and suggestions. We thank Laura Schilz for excellent research assistance. The usual disclaimer applies. Ruth M. Schueler acknowledges financial support by the Economic History Association Exploratory Travel and Data Grant 2014. 


\section{Introduction}

Decentralization of public services to lower levels of government has been a policy objective in the last decade both in developed and developing countries (World Bank, 2004). Generally, it is argued that decentralization allows responding better to people's preference whereas, in a centralized system, the provision of uniform public goods does not reflect local preferences. The standard approach states that in the absence of spillovers and with heterogeneous preferences a decentralized system is to be preferred (Oates, 1972, 1999). Consistently with this view, recent studies have shown that decentralization increases the responsiveness of local governments to local needs (Faguet, 2004; Barankay and Lockwood, 2007; Galiani et al., 2008), although some effect heterogeneities have been unveiled (Galiani et al., 2008; Hanushek et al., 2013).

In this paper we argue that heterogeneous preferences at the local level can lead to a lower provision of public goods if the system is highly decentralized. In particular we study the case of the local provision of public primary education in the presence of different linguistic groups. To address this question we use the historical setting of nineteenth-century Prussia which was, to a large extent, characterized by high linguistic polarization between Germans and Poles and had a highly decentralized education system. Heterogeneous preferences over the local provision of primary education originated from the fact that primary education, and in particular the language of instruction, was used by the German government to Germanize the (mainly) Polish-speaking communities (Lamberti, 1989). Primary education was therefore seen by the Poles as a threat to their cultural identity. At the same time, German-speaking local communities might have had no interest in funding primary education with local tax revenues, as the benefits would largely accrue to non-German speaking groups (Alesina et al. 1999). All this in a highly decentralized educational system as decisions on school funding were taken at the municipal level (Hühner, 1998) ${ }^{1}$.

In order to investigate the impact of linguistic polarization on the local provision of public primary education we use county-level data from different historical censuses. The first comprehensive Prussian education census in 1886 provides detailed information on expenditures on public primary education and on schooling variables such as number of schools, number of teachers, and teacher salaries. For the same level of aggregation we have information on the language spoken by students at home which allows constructing a measure for linguistic polarization.

\footnotetext{
1 This meant explicitly that funding decisions were taken by municipalities, unions of small towns which were called schooling societies, by rural estates, single landlords or individual school patrons.
} 
Cross-sectional evidence shows that, for a given level of municipal tax revenues and development, local expenditure on primary education was systematically lower in counties with high levels of linguistic polarization. Accounting for the subsidiary role of the central state and for a rich set of confounding factors does not affect our main result. Consistently, we find that higher levels of polarization were associated with a lower number of schools per students and a lower teacher-student ratio.

A possible explanation of this result, in line with the theoretical model of Alesina et al. (1999), is that different linguistic groups of similar size had no interest in funding public primary education with local funds. In fact non-German speaking groups perceived primary education policy as a threat to their cultural identity. It is therefore possible that different linguistic groups agreed on the provision of neutral public goods, namely goods not threatening cultural identity. Indeed, we find that linguistic polarization has no bearing on local spending on transport infrastructure such as roads, canals, and railroads, which constituted another major item of public spending. These findings are also consistent with the notion that the under provision of public goods in the presence of heterogeneous preferences should be more accentuated when the group benefitting from the service is clearly identifiable (Alesina et al., 1999; Luttmer, 2001; Vigdor, 2004).

Reverse causality and the omitted variable bias do not allow interpreting our cross-sectional estimates as causal. For instance, a persistently underfunded school system might preserve linguistic polarization, thus generating reverse causality. It is also possible that linguistic polarization and local spending on education are determined by an unobservable variable which varies across counties. We address these issues in the cross-section using an instrumental variable approach. In particular we exploit Prussia's annexation policies to identify arguably exogenous variation in linguistic polarization. The progressive territorial annexations towards Eastern Europe, such as the Partitions of Poland at the end of the eighteenth century, increased the relative number of ethnic Poles in Prussia and thus linguistic polarization. The distance of the newly acquired territories to the eastern border is thus used to identify variation in linguistic polarization. As we include province-fixed effects, annexation fixed-effects, and controls for latitude and longitude, we exploit variation in distance to the border across counties which are otherwise similar in many geographic, institutional, and socio-economic dimensions. The identification strategy rests therefore on the assumption that, conditional on the rich set of controls, distance to the eastern border affects local spending on primary education only through linguistic polarization. 
Instrumental variable estimates confirm the negative impact of linguistic polarization on local spending on public primary education. Importantly, further specifications exclude that the estimated effect is due to the presence of a small (large) German ruling elite which opposes investments in education which would favor the large (small) non-German community. This result is consistent with our interpretation that similarly large linguistic groups opposed the funding of schools with local resources, which then led to a relative underfunding of public primary education.

Following our interpretation, centralization of educational spending could partially solve the problem of under provision in polarized societies as the public good would be financed by the central state and not through local resources. We can test this hypothesis exploiting a policy change towards centralization that occurred in Prussia between 1888 and 1889. For the municipalities the fiscal burden to fund primary education increased tremendously due to the rising number of students and teachers. With the new law the central state aimed at relieving the municipalities from this burden by increasing its contributions. In particular the state granted the municipalities a subsidy to partially cover the costs of teachers (Hühner, 1998). As a result of this policy change the share of state expenditure on primary education increased from about 10 to 35 percent between 1886 and 1891.

Therefore, we estimate the impact of centralization on the provision of primary education across different levels of linguistic polarization. In particular, we estimate a generalized difference-in-difference model with county and year-fixed effects. Our estimate show that after the reform total spending on primary education increased relatively more in polarized counties. Similarly, we find that the initial gap in the number of teachers and in the teacher-student ratio decreased substantially after the reform in polarized counties. These results are consistent with the interpretation that different linguistic groups did not want to fund public primary education with local tax revenues. Our results suggest that centralization of school funding is a possible solution to this problem.

The paper is structured as follows: Section 2 surveys the related literature; Section 3 sets out the historical background of nineteenth-century Prussia education system; Section 4 describes the dataset; Section 5 presents OLS results on the relationship between linguistic polarization and spending in education; Section 6 addresses the issue of causality by presenting estimations on neutral public goods and instrumental variable estimates; Section 7 analyzes the role of centralization in improving the under provision of public education in a panel framework; Section 8 concludes. 


\section{Related literature}

This paper contributes to different strands of literature. First, it contributes to the vast literature on ethnic fractionalization and the provision of public goods. The seminal paper by Alesina et al. (1999) frames a theoretical model linking the heterogeneity of preferences across ethnic groups to the amount and type of public goods provided. The paper furthermore explores the negative association between ethnic fractionalization and a range of public goods using data from U.S. cities, metropolitan areas, and urban counties. The authors argue that the main channel for the negative association is in-group bias, that is, people tending to favor their own kind. Our main result of lower local spending on public primary education in highly polarized counties corroborates the theory of Alesina et al. (1999).

Luttmer (2001) provides support to these results showing that individuals' preferences for income redistribution are affected by the characteristics of others around them. In a similar fashion Vigdor (2004) elaborates a simple model of individual response decision according to which an individual's contribution to local public goods is a positive function of within-group affinity (Vigdor, 2002). Empirically Vigdor (2004) finds that more heterogeneous counties have significantly lower census response rates in 2000, which is intended as an action which generates public benefits. ${ }^{2}$

Miguel and Gugerty (2005) investigate the impact of ethnic diversity on local school funding in Kenya by using historical settlement patterns as an instrument finding that ethnic diversity decreases school funding. In order to establish causality, Dahlberg et al. (2012) and Gerdes (2011) exploit natural experiments that randomly placed refugees across Swedish and Danish municipalities, respectively. Dahlberg et al. (2012) find that previous estimates are positively biased and thereby underestimate the true negative effect of fractionalization on support for redistribution. Gerdes (2011) instead finds no evidence of a decline in the public sector in response to an increase in immigration. ${ }^{3}$

Swee (2015) investigates in the context of Bosnia whether partitioned political jurisdictions provide more public schooling after the war. He finds that partitioned municipalities provide significantly more primary schools and teachers. As partitions induced ethnic homogenization, communities in partitioned municipalities agreed on providing ethnically oriented schools. However, increase in public schooling only benefits children from the dominant ethnic group.

\footnotetext{
${ }^{2}$ See also the more detailed literature review in Alesina and La Ferrara (2005).

${ }^{3}$ For an overview of the recent empirical literature with a focus on the experimental literature see the survey by Stichnoth and Van der Straeten (2013).
} 
From a historical perspective, Chaudhary and Rubin (2015) show how religious identity affects preferences and therefore public policy. The authors exploit a natural experiment in the Indian Princely States where the religion of each ruler as the decision-making authority upon local matters was arbitrary. They find that the provision of public goods was higher in those cases where the religion of the respective ruler and of the population's majority aligned as well as in the absence of private markets.

Hao and Xue (2015) study the relationship between cultural distance between migrants and natives and primary school enrollment rates in historical China at the beginning of the $20^{\text {th }}$ century. They find that a greater cultural distance between natives and migrants has a negative impact on primary school enrollment rates. They argue that high coordination costs between culturally distant groups can explain this finding. Despite many similarities, our paper differs in some crucial aspects. First of all, in our setting we can observe spending on primary education which is a more relevant measure to study the provision of public goods. Second, in our paper we focus on a different dimension of heterogeneity, namely linguistic differences. In our context the cultural distance between the linguistic groups would be virtually constant as the linguistic groups were mainly German-speaking and Polish-speaking communities. This implies that cultural distance likely cannot explain our results. As we will see in the analysis below, diversity in religious denominations cannot affect our main finding either.

We also contribute to the literature on decentralization. Recent studies have shown that decentralization increases the responsiveness of local governments to local needs. Faguet (2004) has shown that decentralization in Bolivia changed the pattern of investments in human capital, water and sanitation, making the provision of public services more related to real local needs. Barankay and Lockwood (2007) using a panel data set of Swiss cantons find that decentralization in education expenditure is associated with higher educational attainment. Similarly, Galiani et al. (2008) find that a longer exposure of secondary schools to decentralization has a positive effect on student test scores in Argentina. However Galiani et al. (2008) uncover some effect heterogeneity as schools located in poor municipalities did not benefit from decentralization. In a cross-country framework Hanushek et al. (2013) show that decentralization in terms of local school autonomy has a positive effect on student achievement in developed countries and a negative impact in developing and low-performing countries. ${ }^{4}$

Finally, our paper contributes also to the literature which aims at explaining the rise of modern school systems. Lindert (2004) attributes the advancement of the Prussian primary

${ }^{4}$ Willis et al. (1999), Bardhan (2002), and Kremer et al. (2003) argue that decentralization leads to inefficient provision of education. 
school system to its decentralized organization both in terms of decision-making and funding as well as to the low-cost provision of teaching staff. Go and Lindert (2010) argue that the expansion of mass schooling in the U.S. took off through increased political voice which was reflected in the electoral support for tax-based schooling. Chaudhary et al. (2012) find that the impact of decentralization on education differed by the political and economic conditions among the elites in the case of Brazil, Russia, India, and China. Gallego (2010) shows that, in the context of fifty former colonies, democracy has a positive effect on primary education whereas political decentralization has a positive and significant impact on secondary and higher education. Cvrcek and Zajicek (2013) look at the Habsburg Empire and find that the expansion of the school system was mainly driven by the political and financial support of local political elites when instruction took place in the "right language".

\section{Historical background}

\subsection{The Prussian school system at the end of the $19^{\text {th }}$ century}

In 1886 Prussia's school system was locally organized and funded (Kuhlemann, 1991). According to Lindert (2004) this was largely responsible for the school system's success. Indeed, Prussia's high school-enrollment and literacy rates made it a role model for other European countries (Clark, 2007).

At the same time, however, the Prussian administration was aware that the school system in the East, and especially in those regions with a high share of Polish-speaking people, lagged behind the rest of the country in terms of student-teacher ratios and enrollment rates largely due to low school-related investments. We argue that lower spending in education in the eastern regions of Prussia stemmed from high linguistic polarization in a context of high decentralization. The historical narrative supports this hypothesis by pointing out that municipalities with a linguistically mixed population suffered especially when it came to the provision of schoolbuildings and teachers, explicitly mentioning the coexistence of different languages as a reason for this situation (Grzes, 1992).

Local organization of schooling meant that the municipality was responsible for levying and allocating school funds (Heinrich et al., 1992; Lamberti, 1989; Lindert, 2004). In many places, provincial or even district legislation regulated school financing, but in the absence of such regional regulations, the Allgemeines Landrecht, the Prussian subsidiary law, held. However, regardless of which law applied, the municipality was the decision-making unit when it came to school finance (Königliches Statistisches Bureau in Berlin, 1889). Schools were separated by 
religious denomination, leading thus to linguistic separation when denomination and language corresponded. ${ }^{5}$

School funding came from various local sources, including tuition fees, foundations, schooling societies, municipal taxes, and contributions from the nobility (patronage). Decisions as to how to allocate school funds were made by the school board (Schulvorstand), which consisted of the noble landlord in the estates or the mayor in urban and rural municipalities, the local clergyman, and two to four members of the school entity (Schulgemeinde) whose election had to be confirmed by the chief administrative officer of the county, the Landrat. In 1887, the likelihood that members of the Polish-speaking population would sit on these school boards decreased when a ministerial decree ruled that the county's Landrat should confirm members of the school board only if would-be members were inclined to foster the German-language policy imposed by the Prussian authorities. The purpose of this decree was to assure that Polish and other minority languages were effectively eliminated from being taught (Glück, 1979). According to Grzes (1992), linguistic barriers and diverging interests led to particular problems in the organization of primary schools in linguistically mixed regions.

In addition to school funding, the municipality was also responsible for appointing teachers (Glück, 1979). However, in July 1886 a new law regarding the appointment of school teachers in the provinces of Posen and West Prussia was enacted. This law shifted the authority to recruit and hire new teachers from the local to the state level in these two provinces (Lamberti, 1989). Before its enactment all decisions on hiring teachers, teacher pay, and facility upgrades were made by the municipalities. ${ }^{6}$

In 1888/89 we observe a partial centralization of spending on public primary education. A new law was passed (Schulunterbaltungsgesetz) which aimed at relieving municipalities from the fiscal burden to fund primary education. The state contributed a fixed sum for each fully employed teacher which amounted to 500 Mark for the first teacher of each school, 300 Mark for every other teacher (150 Marks for every female teacher), and 100 Mark for supplementary teachers. The same law established that school fees would be abolished and that landlords were exempted from their duty to fund schools. As a result of the reform, state spending on primary education

5 Polish-speaking individuals were mostly Catholic and German-speaking individuals were mostly Protestant. However, there were also German-speaking Catholics and a Polish-speaking Protestant minority (Glück, 1979) leading to the fact that the correlation between the share of Polish-speaking students and the share of Catholics only reaches 63 percent. Furthermore, interconfessional mixed schools (Simultanschulen) which were predominant in East Elbia encompassed Catholic and Protestant and therefore Polish- and German-speaking students at the same time (Groeben, 1992).

${ }^{6}$ The law was passed in 1886. However, the actual recruitment of teachers for the provinces of West Posen and Prussia only started in 1887 after a regulation which guaranteed that the relocation costs of teachers would be covered by the state. 
increased on average from 10 percent to 35 percent of the total spending between 1886 and 1891 . The shift to centralization is particularly accentuated if we consider the expenditure on teachers: the state contribution increased from 14 percent to 50 percent.

\subsection{The origins of linguistic polarization in Prussia}

The presence of German and non-German speaking groups in Prussia at the end of the nineteenth-century primarily dates back to the conquest of Pomerania and Silesia in the seventeenth and eighteenth centuries and to the three partitions of Poland at the end of the eighteenth century as well as to the so-called fourth partition of Poland during the Congress of Vienna in 1815 (Hansen and Wenning, 2003). The partitions of Poland had the consequence that one-third of the Prussian population had formerly belonged to the Polish-Lithuanian Commonwealth (Alexander, 2008). These Slavic regions had experienced an immigration of German settlers since the early Middle Ages following the territorial expansion of both the Holy Roman Empire and the Teutonic Order. The result was that Poles and Germans lived side by side, even before these regions became Prussian (Zernack, 2008).

After coming under the Prussian rule, Prussia's active settlement policy, with its objective of populating vacant or devastated land, increased the level of polarization. While settlers initially came from German-speaking regions such as the Palatinate or Franconia, periodic wars and epidemics led to a shortage of German colonizers. This is what ultimately led Lutheran Austrians (Salz̧burger), Masurian Poles, Lithuanians, as well as the French Huguenots, ${ }^{7}$ to be invited to settle in the southern and eastern regions of East-Elbian Prussia. After the three partitions of Poland, the Prussian state authorities reengaged in their population-enhancing policies by supporting German colonizers to settle in the newly acquired Grand Duchy of Posen and, especially, in West Prussia (Zbroschzyk, 2014). The West-to-East migration was only reversed after the foundation of the German Reich when people_-of both Polish and German origin-began to move to the industrialized regions of the Rhineland in the 1880s and 1890s (Wünsch, 2008). ${ }^{8}$

\footnotetext{
${ }^{7}$ For the effect of the Huguenot immigration into Prussia on productivity, see Hornung (2014).

8 The province of Schleswig-Holstein is constituted after the Austro-Prussian War in 1866. As the territories of this newly constituted province formerly belonged to Denmark, a substantial share of Danish-speakers became Prussian. While the share of Danish speakers within the province is at 18 percent, the Danish-speaking minority constitutes only 0.7 percent of the total Prussian population. In the analysis we will exclude the province of Schleswig-Holstein because of the relatively low share of Danish speakers and because of the recent territorial annexation relative to our period of interest. Note that the inclusion of the province of Schleswig-Holstein in the regression analysis does not affect our main results.
} 


\subsection{Prussian language policy throughout the nineteenth century}

Historians concur that it was the foundation of the German Empire in 1871 that ultimately initiated German-Polish antagonism (Alexander, 2008). The German Empire was understood as a nation state, as opposed to the Prussian Empire, which was built on an abstract and fragmentary common identity of its subjects (Clark, 2007).

Until the foundation of the German Empire in 1871, the Prussian authorities considered the Polish- or Slavic-dominated regions as "colonies" with their own cultural identity and, as such, they tolerated the use of Slavic languages and local dialects also in primary schools (Clark, 2007). The right to freely move across inner-Polish borders and to maintain one's Polish identity had been legally protected as early as the Congress of Vienna in 1815 and such rights were strengthened by the edict of 1822, which recognized the importance of language and nationality to Polish-speaking citizens. These rights were also enforced in the primary school system. For example, a regulation of 1842 mandated that the language of school instruction was to be that of the majority of the students (Lamberti, 1989).

After the foundation of the German Reich, Imperial Chancellor Bismarck began to promote Germanization policy. The primary school was to play a key role in this policy by socializing the Polish-speaking students in the east of Prussia (Lamberti, 1989). Several laws were passed in provinces with Slavic minority populations that gradually established German as the only language of instruction. More than half of the curriculum was devoted to German and history lessons aiming at educating loyal Prussian citizens (Lundgreen, 1976). However, the Germanization policy did not achieve its objective of a homogenous German-speaking Prussian nationhood. Instead, Poles began to establish their own parallel society by founding their own banks, organizing themselves in clubs, and passing on Polish-specific human capital in confirmation classes (Alexander, 2008). ${ }^{9}$ In fact, the foundation of Polish cooperatives was a central aspect of the Polish national movement (Suesse and Wolf, 2014).

This parallel structure meant that Germans and Poles rarely interacted voluntarily in everyday life, which inhibited the exchange between the two groups that could have resulted in shared values and beliefs, and, consequently, more cooperation. The social conflict between Germans and Poles peaked with the Polish school strikes in the city of Wreschen in 1901 and in the province of Posen in 1906 (Lamberti, 1989). During the school strike in Posen in 1906 46,886 out of 379,633 children in 755 out of the 2,862 schools boycotted school attendance after German

9 Alexander (2008) argues that the Prussian policy against linguistic minorities and especially against the Poles eventually led to Prussia's decline. 
had been introduced as the only language of instruction in additional 200 primary school (Unruh, 1992).

Overall, 1886 is described as the heyday of Bismarck's policy against the Poles (Neubach, 1992) due to the discriminatory legislation which included the promotion of "Germanness" (Deutschtum) in Posen and West Prussia and the settlement law which aimed at systematically buying land estates possessed by Poles. Another discriminatory law was the ban of Polish student associations at German universities (Kuhlemann, 1991).

\section{Data}

We have collected and digitized data from the first comprehensive educational census of 1886 which was published by the Royal Statistical Office of Prussia (Königliches Statistisches Bureau in Berlin, 1889). The educational census was conducted every five years from 1886 until 1911 and after World War I in 1921 and 1926. The census provides detailed and comprehensive information on enrollment rates, school facilities, teachers, class size, school organization, teacher income, and students' language for a total of 451 counties, the smallest administrative unit in Prussia. The east Elbian part of Prussia, which constitutes the focus of our cross-sectional analysis, encompasses 214 counties.

For our cross-sectional analysis we use the first comprehensive education census done in 1886 since that was the last census-year in which the education system was highly decentralized and the central state played only a marginal role. In fact, the share of state contribution was only 10 percent while the rest was financed through local spending. In 1891, instead, state contributions reached already 35 percent of the total expenditure on public primary education.

\subsection{Measuring linguistic polarization in Prussia}

The education census of 1886 reports the language spoken in the students' home. The census distinguishes between German, Polish, Lithuanian, Masurian, Slavic, Danish, and "other" languages. The census also contains information on whether the reported language is the only one spoken at home or whether both German and another language are spoken at home. When constructing the index of linguistic polarization we include the latter category of bilingual students in the group of non-German speakers. We assume that the interests of this bilingual group are more aligned with the interests of the non-German speaking community. ${ }^{10}$

\footnotetext{
${ }^{10}$ In any case, assigning the bilingual group to the German-speaking group does not affect our results.
} 
We measure the antagonism between Germans and other linguistic groups by using the polarization index proposed by Esteban and Ray (1994), ${ }^{11}$ which is also employed by Fearon and Laitin (2003) and Collier and Hoeffler (2004), among others. As the Prussian case is characterized mainly by the dualism between Germans and Polish people rather than by a conflict between several linguistic groups, the use of the polarization index instead of the fractionalization index is more recommended. Recent work by Esteban et al. (2012) shows that linguistic polarization is related to conflict over public goods, while fractionalization increases conflict over private goods. The polarization index measures how far the distribution of the groups is from a bipolar distribution, which represents the highest level of polarization. Our polarization index has the following form:

$$
P o l=1-\sum_{i}\left(\frac{\frac{1}{2}-\pi_{i c}}{\frac{1}{2}}\right)^{2} \pi_{i c}
$$

where $\pi_{i c}$ denotes the share of the linguistic group $i$ in county $c$. Thus, the polarization index varies between 0 and 1 . In our case, polarization equals 1 if, for example, 50 percent of the students speak German and the other 50 percent speak Polish at home.

\subsection{Outcome variables and controls}

Our outcomes in terms of educational spending are also constructed from the education census of 1886. The educational census is very detailed and permits distinguishing between educational expenditures stemming from local and national sources. Local funds are comprised of tuition fees and money from foundations, schooling societies, municipalities, patronage, or other sources. National funds are comprised of state funds and state grants that were mainly targeted at municipalities incapable of independently funding their schools (Lamberti, 1989). We measure local school spending by the amount of local expenditure per child of mandatory school age (6-14). Successively we also look at "real" school variables such as the number of schools per child and the teacher-student ratio.

To control for initial differences in both the supply and demand for education, we use data on the share of Protestants, the urbanization rate and population density from the population census of 1885, the fraction of people employed in agriculture or manufacturing, and

${ }^{11}$ For a discussion on which polarization index to use, see Duclos et al. (2004), Montalvo and Reynal-Querol (2005) and Esteban and Ray (2012). 
landownership concentration from the occupational census of $1882 .{ }^{12}$ We have also digitized data on municipal tax revenues in 1883/1884 from the census of Prussian urban and rural municipalities and data on secular school inspectors from the Zentralblatt of 1886. The latter is an important control variable as we aim at separating the effect of linguistic polarization on public spending on education from the Kulturkampf, which aimed at weakening the role of the Catholic Church in providing public secular education in the Catholic-Polish areas.

In the attempt to identify the impact of linguistic polarization, we also account for religious fractionalization in 1871, which, especially in the context of East Prussia, is positively correlated with linguistic heterogeneity. We account for religious fractionalization using the standard measure related to the Herfindahl index:

$$
\operatorname{Frac}_{c}=1-\sum_{i} s_{i c}^{2}
$$

where $s_{i c}$ denotes the share of the religious group $i$ in county $c$. This index is based on five religious denominations as reported in the census: Catholic, Protestant, other Christian, Jewish, and other religion. The fractionalization index, which varies also between 0 and 1 , measures the probability that two individuals randomly drawn from a population belong to a different denomination. The index increases monotonically with the number of groups in a county. For a given number of groups, the index increases as the share of religious groups is more equally distributed. ${ }^{13}$

For the panel analysis on the effect of centralization on school outcomes for different levels of linguistic polarization, we digitized information from the education census of 1891 and 1896. This enables us to exploit a reform that substantially increased the share of state funds on total spending on public primary education in $1888 / 89 .{ }^{14}$

\subsection{Descriptive statistics}

Prussia did not pass a universal law on school funding until 1906 (Anderson, 1970; Lamberti, 1989). Prior to the law's passage provincial regulations or customary law at the regional level set

12 Some of the control variables are taken from the ifo Prussian Economic History Database (iPEHD). For a more detailed description of the sources, see Becker et al. (2014).

${ }^{13}$ Note that since we have five religious denominations, the fractionalization index can only reach the maximum value of 0.8 .

${ }^{14}$ Education censuses are available also for 1901, 1906 and 1911. Yet, in 1897 a law on minimum teacher wages was passed and that further changed how state funds were allocated (Lamberti, 1989). Therefore we decided to restrict our panel analysis to the census years 1886, 1891, and 1896. 
out guidelines for school funding. This ultimately led to very different funding schemes across the six eastern provinces. Table 1 reports the descriptive statistics of the variables used in our analysis for the East-Elbian counties in 1886.

The table shows that there is a wide variation in local and state spending. Average local spending on primary education in 1886 in East Prussia was about 13 Marks per child aged 6-14. This expenditure varied dramatically from a minimum of 7.75 Marks to a maximum of 37 Marks. State expenditure on primary education was on average 2 Marks per child. The largest part of the local educational expenditure went to teacher salaries: on average, teacher salary constitute 63 percent of total local school spending, whereas expenditures for the construction, expansion and renovation of school buildings account for 15 percent, and expenditures for the maintenance of schools sums up to 22 percent of total school funds.

As for the linguistic groups, Germans and Poles are the two dominant groups at 75 and 22 percent, respectively. The polarization index has an average value of 0.29. In our sample, 167 out of 214 counties experienced some level of polarization. There are 47 counties (22 percent) in which non-German speaking people constitute the majority. The geographic distribution of linguistic polarization is shown in Figure 1. Overall, linguistic polarization increases the closer a county is to the eastern border of Prussia. Yet, the counties on the border have a comparatively lower level of polarization as in 21 out of 25 counties on the border German-speaking people constitute the minority. 


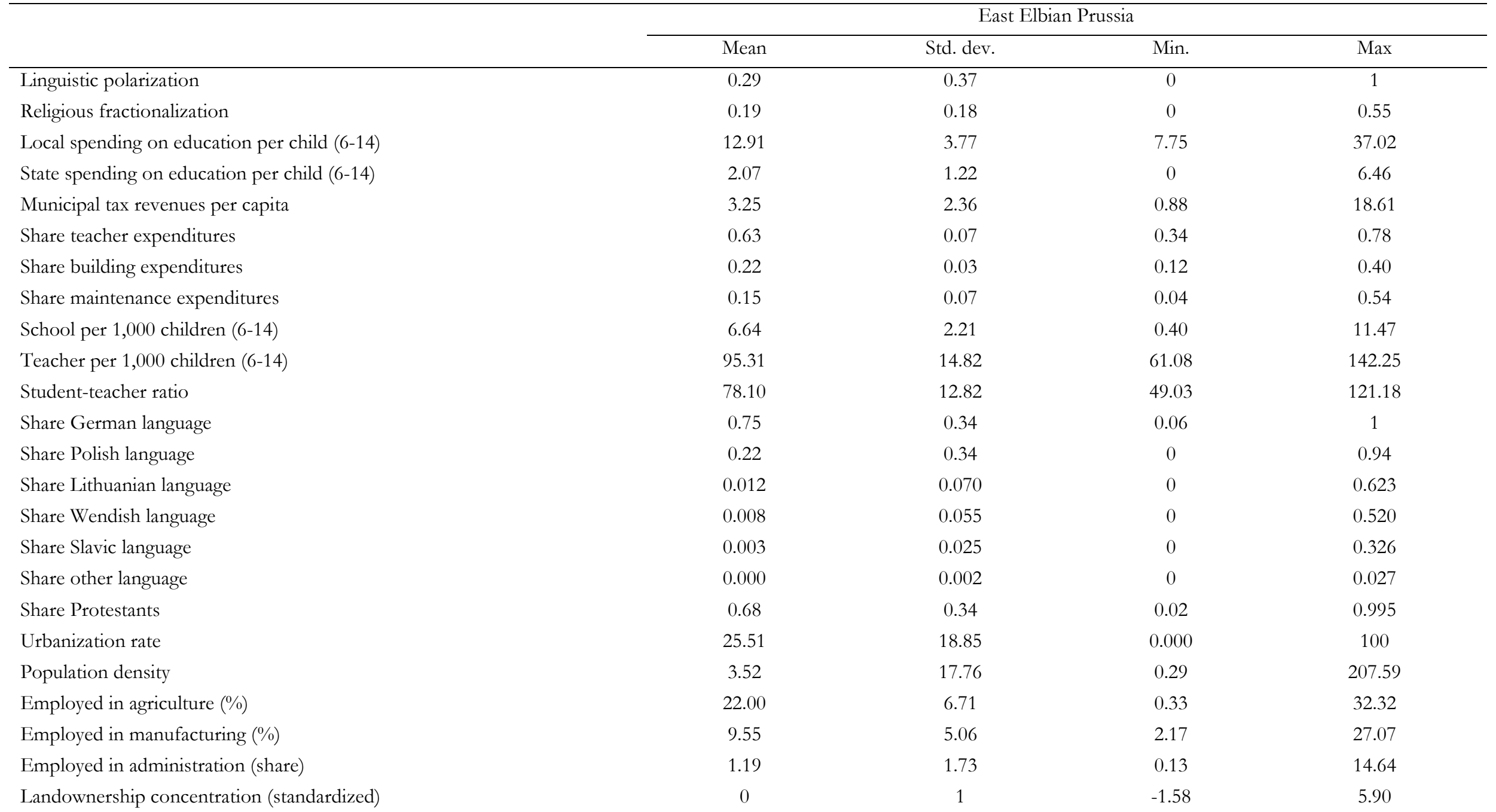

Note: Summary statistics of selected key variables for East-Elbian counties, excluding Schleswig-Holstein ( $\mathrm{n}=214$ ). Linguistic polarization is measured through the polarization index as described in equation (1) and is based on six linguistic groups as reported in the education census in 1886: German, Polish, Lithuanian, Masurian, Slavic, and "other" language. Religious fractionalization is measured through the fractionalization index as in equation (2) and is based on five religious groups as reported in the population census in 1871: Protestants, Catholics, other Christians, Jews, and other religion. See text for sources. 


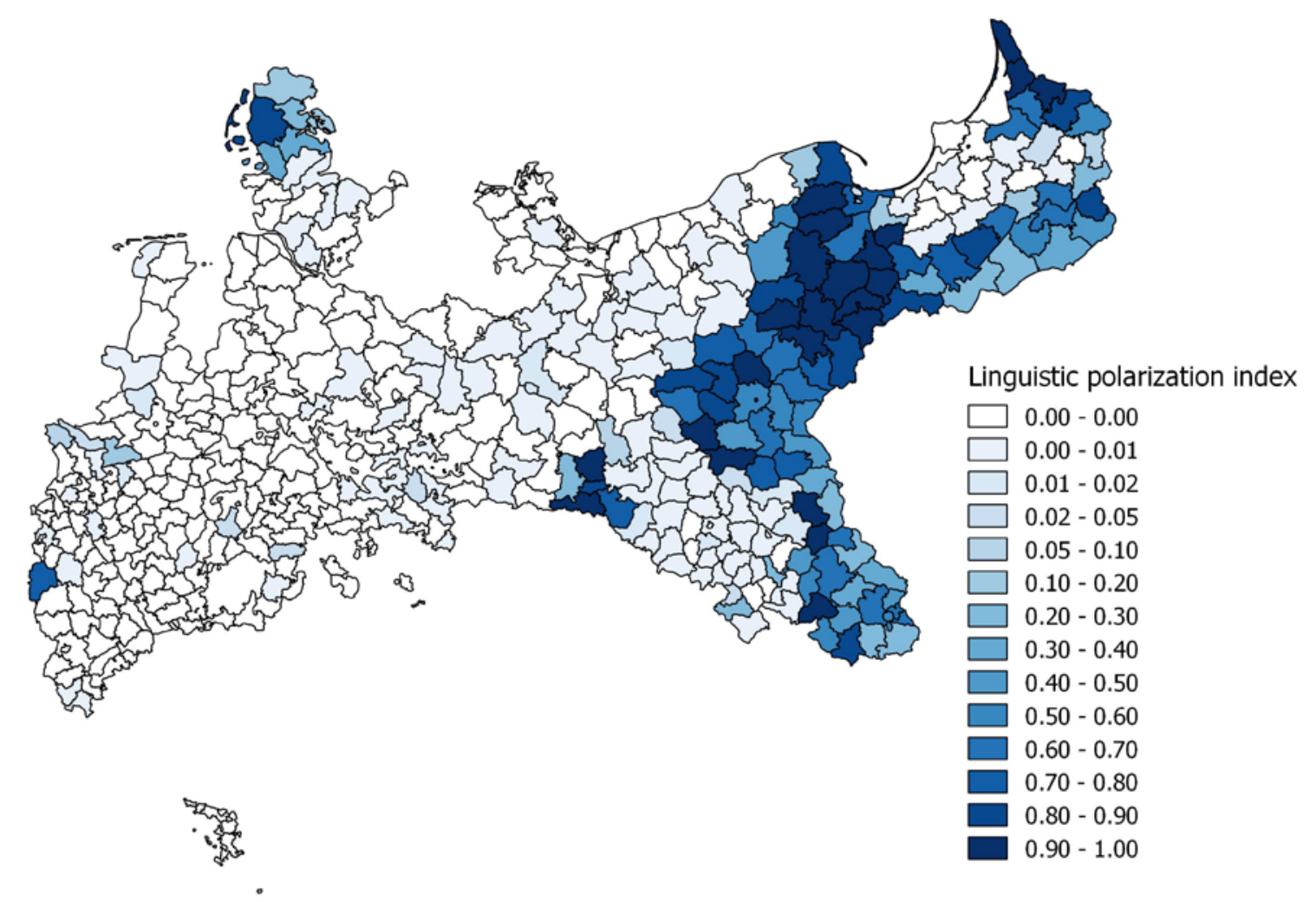

Figure 1: Linguistic polarization across Prussian counties in 1886.

Note: Linguistic polarization is measured through the polarization index as described in equation (1) and is based on the linguistic groups as reported in the education census in 1886: German, Polish, Lithuanian, Masurian, Slavic, Danish and “other” language. County borders as in 1871. 


\section{Linguistic polarization and local spending on education}

We start exploring the association between linguistic polarization and local school funding estimating an OLS model as in equation (3). We focus on the East-Elbian counties as linguistic polarization in the western part of the country is virtually zero (mean 0.01).

$$
\log \text { (loc. spending p. c. })_{c}=\beta_{1} P_{o l}+X_{c}^{\prime} \gamma+\alpha_{p}+\theta_{a}+\varepsilon_{c}
$$

We use as dependent variable the logarithm of local spending on primary education per child of mandatory school age (6-14) for county $c$. Pol $_{c}$ is the index of linguistic polarization computed at the county level and $X$ is a vector of covariates.

We include also province fixed effects $\left(\alpha_{p}\right)$ and annexation fixed-effects $\left(\theta_{a}\right)$. As school funding was organized locally, funding schemes might have varied substantially across provinces which had different rules concerning the education policy. The period and geography of annexation are also important variables to account for. In fact, different annexations had different "settlement policies" (Ansiedlungspolitik) which could be related to both linguistic polarization and local spending on education. In addition, different annexations imply also a different number of years under the Prussian rule which might have an impact on both polarization and spending on education. In Figure 2 we show a map of the Prussian territorial annexations which occurred at different points in time. In the regression we include indicators for the following annexations: the Margraviate of Brandenburg, the Duchy of Prussia, Eastern and Western Pomerania, Silesia, the First and Second Partitions of Poland, and the territories acquired with the Vienna Congress. ${ }^{15}$

The OLS estimates are presented in Table 2. The unconditional correlation between linguistic polarization and local school funding is negative and highly significant (column 1). In column 2 we include the province and annexation fixed-effects. The negative impact of linguistic polarization remains highly significant even when we exploit variation within provinces or variation within annexations.

15 As the counties in Magdeburg east of the river Elbe are only 4, in the empirical analysis we merge these counties with the Margraviate of Brandenburg. 


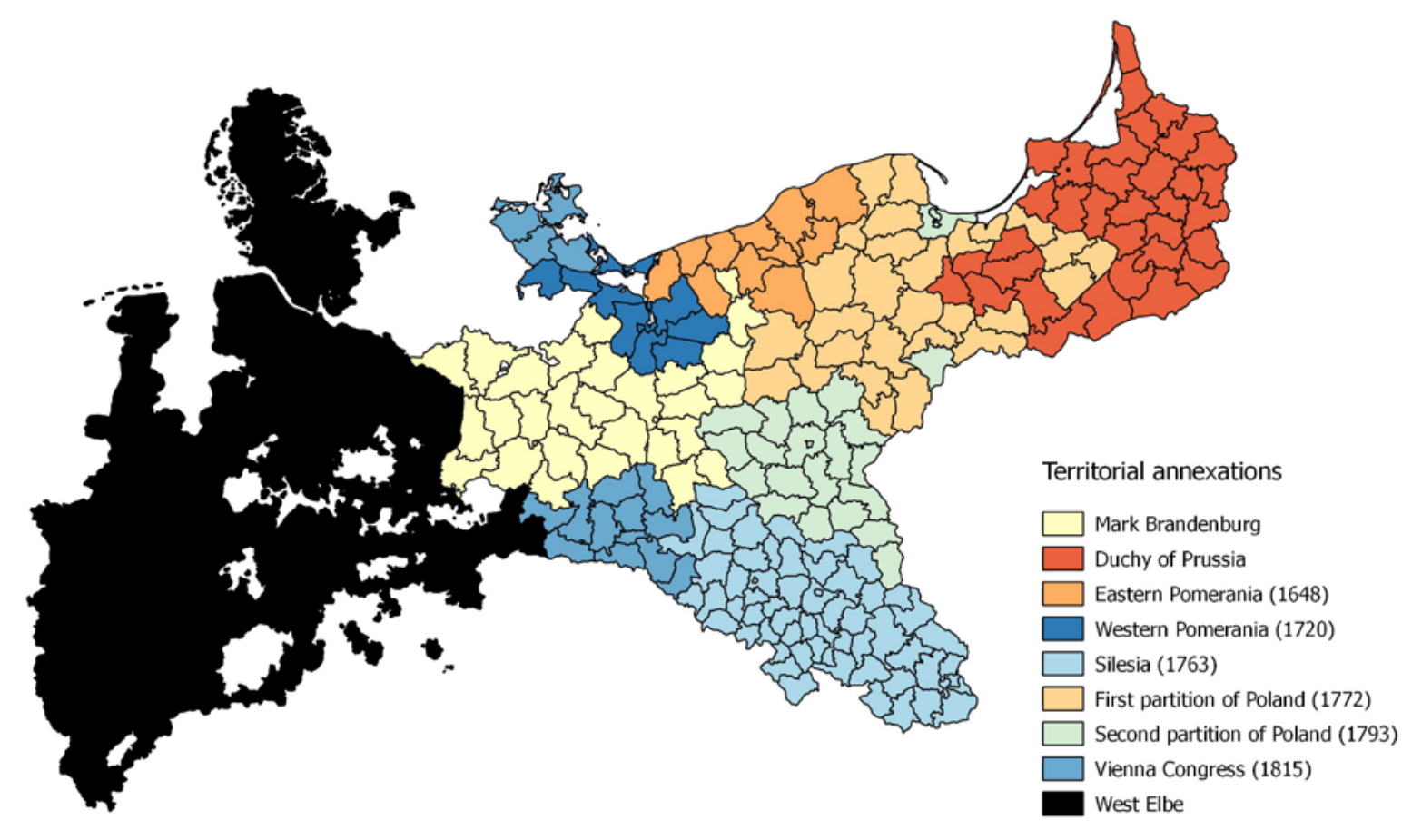

$x$

Figure 2: Territorial annexations of the Kingdom of Prussia.

Note: County borders as in 1871. 
Table 2: Linguistic polarization and local spending on education: OLS estimates

\begin{tabular}{|c|c|c|c|c|c|c|c|c|}
\hline & $(1)$ & $(2)$ & (3) & (4) & (5) & (6) & (7) & $\begin{array}{c}(8) \\
\text { Full sample }\end{array}$ \\
\hline Linguistic polarization & $\begin{array}{c}-0.334 * * * \\
(0.038)\end{array}$ & $\begin{array}{c}-0.221^{* * *} \\
(0.042)\end{array}$ & $\begin{array}{c}-0.131 * * * \\
(0.043)\end{array}$ & $\begin{array}{c}-0.130^{* * *} \\
(0.046)\end{array}$ & $\begin{array}{c}-0.139 * * * \\
(0.051)\end{array}$ & $\begin{array}{c}-0.165^{* * *} \\
(0.044)\end{array}$ & $\begin{array}{c}-0.157 * * * \\
(0.047)\end{array}$ & $\begin{array}{c}-0.148^{* * *} \\
(0.042)\end{array}$ \\
\hline Religious fractionalization & & & & $\begin{array}{l}-0.006 \\
(0.120)\end{array}$ & $\begin{array}{l}-0.061 \\
(0.140)\end{array}$ & & $\begin{array}{l}-0.079 \\
(0.113)\end{array}$ & $\begin{array}{c}0.076 \\
(0.056)\end{array}$ \\
\hline Linguistic polarization $\mathrm{x}$ religious fract. & & & & & $\begin{array}{c}0.128 \\
(0.199)\end{array}$ & & & \\
\hline Log municipal tax p.c. & & & & & & $\begin{array}{c}0.141 * * * \\
(0.036)\end{array}$ & $\begin{array}{c}0.145^{* * *} \\
(0.036)\end{array}$ & $\begin{array}{c}0.160^{* * *} \\
(0.031)\end{array}$ \\
\hline Protestant & & & $\begin{array}{c}0.077 \\
(0.055)\end{array}$ & $\begin{array}{c}0.078 \\
(0.064)\end{array}$ & $\begin{array}{c}0.081 \\
(0.062)\end{array}$ & $\begin{array}{l}0.100^{*} \\
(0.052)\end{array}$ & $\begin{array}{l}0.119 * \\
(0.061)\end{array}$ & $\begin{array}{c}0.150 * * * \\
(0.034)\end{array}$ \\
\hline Urbanization & & & $\begin{array}{c}0.583^{* * *} \\
(0.126)\end{array}$ & $\begin{array}{c}0.583^{* * *} \\
(0.126)\end{array}$ & $\begin{array}{c}0.586^{* * *} \\
(0.126)\end{array}$ & $\begin{array}{c}0.408^{* * *} \\
(0.127)\end{array}$ & $\begin{array}{c}0.406^{* * *} \\
(0.126)\end{array}$ & $\begin{array}{c}0.286^{* * *} \\
(0.071)\end{array}$ \\
\hline Population density & & & $\begin{array}{c}0.002^{* * *} \\
(0.001)\end{array}$ & $\begin{array}{c}0.002^{* * *} \\
(0.001)\end{array}$ & $\begin{array}{c}0.002^{* * *} \\
(0.001)\end{array}$ & $\begin{array}{c}0.002^{* * *} \\
(0.000)\end{array}$ & $\begin{array}{c}0.002^{* * *} \\
(0.001)\end{array}$ & $\begin{array}{c}0.001 \\
(0.001)\end{array}$ \\
\hline Landownership conc. & & & $\begin{array}{l}-0.002 \\
(0.011)\end{array}$ & $\begin{array}{l}-0.002 \\
(0.011)\end{array}$ & $\begin{array}{l}-0.003 \\
(0.011)\end{array}$ & $\begin{array}{l}-0.001 \\
(0.011)\end{array}$ & $\begin{array}{c}0.001 \\
(0.011)\end{array}$ & $\begin{array}{c}0.015 \\
(0.013)\end{array}$ \\
\hline Emp. in agriculture & & & $\begin{array}{c}0.005 \\
(0.005)\end{array}$ & $\begin{array}{c}0.005 \\
(0.005)\end{array}$ & $\begin{array}{c}0.005 \\
(0.005)\end{array}$ & $\begin{array}{l}0.008^{*} \\
(0.005)\end{array}$ & $\begin{array}{l}0.008^{*} \\
(0.005)\end{array}$ & $\begin{array}{l}-0.003 \\
(0.003)\end{array}$ \\
\hline Emp. in manufacturing & & & $\begin{array}{l}0.011 * \\
(0.006) \\
\end{array}$ & $\begin{array}{l}0.011 * \\
(0.006) \\
\end{array}$ & $\begin{array}{l}0.011 * \\
(0.006) \\
\end{array}$ & $\begin{array}{c}0.009 \\
(0.006) \\
\end{array}$ & $\begin{array}{c}0.009 \\
(0.006) \\
\end{array}$ & $\begin{array}{c}0.002 \\
(0.004) \\
\end{array}$ \\
\hline Province FE & No & Yes & Yes & Yes & Yes & Yes & Yes & Yes \\
\hline Annexation FE & No & Yes & Yes & Yes & Yes & Yes & Yes & No \\
\hline Observations & 214 & 214 & 214 & 214 & 214 & 214 & 214 & 451 \\
\hline R-squared & 0.25 & 0.38 & 0.67 & 0.67 & 0.67 & 0.70 & 0.70 & 0.71 \\
\hline
\end{tabular}

Note: OLS estimates. The dependent variable is the logarithm of local spending on public primary education per child of mandatory school age (6-14). Linguistic polarization is measured through the polarization index as described in equation (1) and is based on six linguistic groups as reported in the education census in 1886: German, Polish, Lithuanian, Masurian, Slavic, and "other" language. Religious fractionalization is measured through the fractionalization index as in equation (2) and is based on five religious groups as reported in the population census in 1871: Protestants, Catholics, other Christians, Jews, and other religion. Log municipal tax p.c. denotes the log municipal tax revenues per capita for the fiscal year 1883/1884. Protestant denotes the share of Protestants in 1885. Urbanization is the share of people living in cities in 1885. Population density is the number of people per hectare in 1885. Landownership concentration is constructed as the number of farms larger than 100 ha over the total number of farms in 1882 and is standardized with zero mean and unit standard deviation. Emp. in agriculture (manufacturing) denotes the percentage of people employed in agriculture (manufacturing) in 1882. Province fixed-effects include six provinces. Annexation fixed effects include eight territories. Robust standard errors are reported in parentheses. $* * *, * *$, and $*$ denote significance at $10 \%, 5 \%$, and $1 \%$, respectively. 
The coefficient in column 2 implies that moving from a county with zero polarization (i.e. 100\% German-speaking) to a county with full polarization (i.e. 50\% German speaking and 50\% Polish speaking) is associated with a decrease in local spending on primary education of about $22 \%$.

In column 3 we include our set of covariates, namely the share of Protestants, the share of people living in cities, population density, landownership concentration, the share of people employed in agriculture and in manufacturing, respectively. The share of Protestants accounts for the fact that Protestant regions have higher levels of literacy as a result of Luther's preach that every Protestant should be able to read the Bible (Becker and Woessmann, 2009). Counties with a large share of Protestants are thus expected to have also a higher spending on education. Throughout the analysis we will find such a positive association.

As for the percentage of people employed in agriculture and manufacturing, Becker et al. (2011) have shown that primary education played an important role in Prussia's effort to catch up with early-industrializer Britain. The estimates in column 3 show a weak positive association between the percentage of people employed in manufacturing and local school spending. Cinnirella and Hornung (2016) showed that the concentration of large landownership and the institution of serfdom slow the accumulation of education. In our OLS specifications we do not find a significant relationship between landownership concentration and local spending in education. Instead, we find that population density and urbanization are positively related to school spending. Compared to the bivariate model in column 1, the coefficient for linguistic polarization in column 3 is smaller in size but still precisely estimated. This specification explains 67 percent of the variation in local spending in primary education.

Religious fractionalization could be an important confounding factor as in the context of East Prussia linguistic differences overlap to a considerable extent with religious denominations. In column 4 we include the measure for religious fractionalization based on the Herfindahl index. The coefficient has a negative sign but is not statistically significant. One could argue that linguistic polarization has an impact on education spending which varies with religious fractionalization. However, the interaction between linguistic polarization and religious fractionalization (centered at the mean) in column 5 is not significant and the coefficient for polarization is virtually unaffected.

Counties characterized by high levels of linguistic polarization could be less economic prosperous and therefore could afford less education. It is therefore crucial to account for systematic differences in economic prosperity. In fact, since we hypothesize that different linguistic groups had different preferences on how to locally fund primary education, it is important to level out differences in tax revenues. The best measure available at the county level 
for the period under consideration is municipal tax revenues per capita for the years 1883/1884. We include this variable in column 6. Indeed, we find that log municipal tax revenues are strongly positively associated with log local spending on primary education. Since municipal tax rates are also measured in logarithm, we can interpret the coefficients as elasticity: an increase of municipal tax revenues by 1 percent is associated with an increase in school spending of 0.14 percent. Importantly, we find that accounting for the level of municipal tax revenues, local spending on public primary education is still significantly lower in counties with higher levels of linguistic polarization. If anything, accounting for differences in municipal tax revenues increases the coefficient on linguistic polarization.

In column 7, we include all the control variables, with the exclusion of the interaction between linguistic polarization and religious fractionalization which is never significant. The coefficient on linguistic polarization is highly significant and virtually unchanged in magnitude.

Finally, in column 8 we test whether the association between polarization and local spending on education holds also for entire Prussia. The negative coefficient remains highly significant and similar in magnitude.

\section{Addressing causality}

The previous estimates indicate that the negative relationship between linguistic polarization and local spending on public primary education is not due to differences in religious affiliation, municipal tax revenues, urbanization, and the industrial structure. Despite our rich set of control variables, omitted variables and reverse causality might bias the OLS estimates. It is reasonable to assume that a systematically underfunded school system contributed to the persistence of a high level of linguistic polarization. Additionally, there could be an omitted variable that affects both local spending on education and the linguistic composition of the population. Segregated labor markets or occupational sorting between German and non-German speaking groups could constitute such omitted variable.

\subsection{Linguistic polarization and neutral public goods}

A first attempt to address the issue of causality is by looking at the provision of neutral public goods. Our hypothesis is that different linguistic groups have polarized preferences over the type of public education to provide and they are reluctant to fund public education with local tax revenues. If this is the case, we should not find any relationship between linguistic polarization and the provision of other neutral public goods. In particular, we expect that the provision of public goods not related to any specific cultural trait is not correlated with linguistic polarization. 
We can test this hypothesis by looking at local spending on transport infrastructure such as roads, canals, bridges, harbors, railways, street cleaning, surveying and mapping, gardening, and other related tasks which also fell within the ambit of the municipal administration (Hühner, 1998). Data on local spending on infrastructure have been digitized from the official statistics on municipal taxes for the years 1883/84 (Königliches Statistisches Bureau in Berlin, 1884). The same source provides data also on local spending on institutions for poor relief. Poor relief was regulated through the Allgemeines Landrecht. Groups of municipalities or land estates were responsible for the local poor and set the level of financial support. Poor relief encompassed preventive and direct support. Preventive support included the allocation of labor, the education of disadvantaged children, and free healthcare. Direct support included the provision of working houses and orphanages as well as monetary and nonmonetary contributions (Hühner, 1998).

As discussed above, we expect linguistic polarization to be uncorrelated with the local provision of transport infrastructure as both linguistic groups probably benefited from such public good. The expected impact of linguistic polarization on poor relief is instead ambiguous. In a polarized society, spending on poor relief might have been kept low not to favor the disadvantaged rival group. We also have to bear in mind that part of the poor-relief expenditure was devoted to educational items such as the coverage of school fees for disadvantaged children.

In columns 1 and 2 of Table 3 we provide OLS estimates using as dependent variable log local spending on transport infrastructure and poor relief per capita, respectively. The estimates in column 1 provide support to our hypothesis that linguistic polarization has no bearing on the provision of neutral public goods. The coefficient for linguistic polarization is basically zero.

The coefficient for linguistic polarization using local spending on poor relief as dependent variable (column 2), though not significant, is negative and similar in size to the estimates of Table 2. Since the potential beneficiaries of poor relief were clearly identifiable across linguistic group, this result is consistent with the interpretation that equally large linguistic groups oppose the local provision of public goods which would benefit the antagonistic group.

\subsection{Instrumental variable approach}

In this section we propose an instrumental variable which addresses the issues of omitted variable bias and reversed causality. In particular we exploit the geographic distribution of the non-German speaking groups driven by the territorial acquisitions of Prussia towards East. As displayed in Figure 1, linguistic polarization tends to increase as we move towards the eastern border. Thus, we identify variation in linguistic polarization using the geodesic distance of the county centroid to the eastern border. We use a quadratic function of distance as the impact on 
end up exploiting variation of neighboring counties, arguably similar in their geographic and socio-economic characteristics.

Formally our first stage is the following:

$$
\text { Polarization }_{c}=\beta_{1} \text { Dist }_{c}+\beta_{2} \text { Dist }_{c}^{2}+X_{c}^{\prime} \gamma+\alpha_{p}+\theta_{a}+\varepsilon_{c}
$$

where Polarization denotes the linguistic polarization index in 1886; Dist is the geodesic distance (in $100 \mathrm{~km}$ ) from the county centroid to the eastern border. The vector $\mathbf{X}$ includes the control variables as in equation (3), plus an indicator for the counties on the border, latitude, longitude and their interaction, distance to the capital of the province, and distance to Berlin.

Estimates from the instrumental variable approach are presented in Table 4. In the sake of comparison we report in column 1 the baseline OLS estimates corresponding to column 7 of Table 2. First stage estimates are presented in column 2. The coefficients on distance and its quadratic term support our assumption of a negative and decreasing relationship between distance to the eastern border and linguistic polarization. ${ }^{16}$ Second stage estimates in column 3 confirm the negative impact of linguistic polarization on local spending on education. In column 4 we include latitude, longitude, and their interaction. This strengthens the power of our instrumentation as indicated by the fist-stage F-statistics reported at the bottom of the table. The effect of polarization remains similar in size and is more precisely estimated. In column 5 we further include the indicator variable for the counties at the border, distance to the capital of the province, ${ }^{17}$ and distance to Berlin. It can be argued that educational policies were more strictly enforced the closer a county is to the capital Berlin, or to the main provincial city. However these additional controls have no impact on the effect of linguistic polarization on local spending on primary education.

The magnitude of the IV coefficient indicates that the OLS estimates slightly underestimate the effect of polarization on local spending. It is likely that distance to the border identifies conflict areas where the impact of linguistic polarization is more salient, granting then a LATE interpretation of the IV estimates.

16 The variable distance to the eastern border has a mean of $221 \mathrm{~km}(\mathrm{std} . \mathrm{dev} .165 \mathrm{~km})$ and ranges from $7 \mathrm{~km}$ to $667 \mathrm{~km}$ in the regression sample. The distance from the eastern border that minimizes the quadratic function in the richest specification in column 5 of Table 4 is $591 \mathrm{~km}$.

17 The cities are: Breslau, Danzig, Koenigsberg, Magdeburg, Posen, Potsdam, and Stettin. 
Table 4: Linguistic polarization and local spending on education: IV estimates

\begin{tabular}{|c|c|c|c|c|c|}
\hline & \multirow{2}{*}{$\begin{array}{l}\text { OLS } \\
(1)\end{array}$} & \multirow{2}{*}{$\begin{array}{c}\text { First stage } \\
\text { (2) }\end{array}$} & \multicolumn{3}{|c|}{ Instrumental variables } \\
\hline & & & (3) & (4) & (5) \\
\hline \multirow[t]{2}{*}{ Linguistic polarization } & $-0.157 * * *$ & & $-0.254^{*}$ & $-0.258 * *$ & $-0.226^{*}$ \\
\hline & $(0.047)$ & & $(0.136)$ & $(0.124)$ & $(0.121)$ \\
\hline Distance & & $\begin{array}{c}-0.180^{* * *} \\
(0.048)\end{array}$ & & & \\
\hline Distance squared & & $\begin{array}{c}0.019 * * * \\
(0.006)\end{array}$ & & & \\
\hline \multirow[t]{2}{*}{ Religious fractionalization } & -0.079 & $0.782^{* * *}$ & -0.005 & -0.132 & -0.180 \\
\hline & $(0.113)$ & $(0.200)$ & $(0.151)$ & $(0.130)$ & $(0.149)$ \\
\hline \multirow[t]{2}{*}{ Log municipal tax p.c. } & $0.145^{* * *}$ & $0.120^{*}$ & $0.157 * * *$ & $0.165^{* * *}$ & $0.164 * * *$ \\
\hline & $(0.036)$ & $(0.065)$ & $(0.039)$ & $(0.035)$ & $(0.034)$ \\
\hline \multirow[t]{2}{*}{ Protestant } & $0.119^{*}$ & $-0.232^{* *}$ & 0.082 & $0.113^{*}$ & $0.134 *$ \\
\hline & $(0.061)$ & $(0.101)$ & $(0.077)$ & $(0.067)$ & $(0.072)$ \\
\hline \multirow[t]{2}{*}{ Urbanization } & $0.406^{* * *}$ & $-0.514 * * *$ & $0.349 * * *$ & $0.389 * * *$ & $0.406^{* * *}$ \\
\hline & $(0.126)$ & $(0.142)$ & $(0.135)$ & $(0.125)$ & $(0.122)$ \\
\hline \multirow[t]{2}{*}{ Population density } & $0.002 * * *$ & -0.000 & $0.002 * * *$ & $0.002 * * *$ & $0.002^{* * *}$ \\
\hline & $(0.001)$ & $(0.001)$ & $(0.000)$ & $(0.000)$ & $(0.001)$ \\
\hline \multirow{2}{*}{ Landownership conc. } & 0.001 & $-0.058^{* * *}$ & -0.006 & $-0.024^{*}$ & $-0.027 * *$ \\
\hline & $(0.011)$ & $(0.018)$ & $(0.013)$ & $(0.013)$ & $(0.013)$ \\
\hline \multirow[t]{2}{*}{ Emp. in agriculture } & $0.008^{*}$ & -0.010 & 0.007 & $0.012^{* * *}$ & $0.013^{* * *}$ \\
\hline & $(0.005)$ & $(0.007)$ & $(0.005)$ & $(0.004)$ & $(0.004)$ \\
\hline \multirow[t]{2}{*}{ Emp. in manufacturing } & 0.009 & $-0.017 *$ & 0.006 & $0.012^{*}$ & $0.013^{* *}$ \\
\hline & $(0.006)$ & $(0.009)$ & $(0.007)$ & $(0.006)$ & $(0.006)$ \\
\hline Latitude, longitude and their interaction & No & No & No & Yes & Yes \\
\hline Additional controls & No & No & No & No & Yes \\
\hline Province FE & Yes & Yes & Yes & Yes & Yes \\
\hline Annexation FE & Yes & Yes & Yes & Yes & Yes \\
\hline Observations & 214 & 214 & 214 & 214 & 214 \\
\hline Kleibergen-Paap rk Wald F statistic & & & 7.1 & 12.2 & 12.1 \\
\hline \multicolumn{6}{|c|}{$\begin{array}{l}\text { Note: OLS and IV estimates. The dependent variable is the logarithm of local spending on public primary education. In column } 2 \\
\text { the dependent variable is linguistic polarization. Linguistic polarization is measured through the polarization index as described in } \\
\text { equation (1) and is based on six linguistic groups as reported in the education census in 1886: German, Polish, Lithuanian, } \\
\text { Masurian, Slavic, and "other" language. Religious fractionalization is measured through the fractionalization index as in equation } \\
\text { (2) and is based on five religious groups as reported in the population census in 1871: Protestants, Catholics, other Christians, } \\
\text { Jews, and other religion. Log municipal tax p.c. denotes the log municipal tax revenues per capita for the fiscal year } 1883 / 1884 \text {. } \\
\text { Protestant denotes the share of Protestants in 1885. Urbanization is the share of people living in cities in 1885. Population density } \\
\text { is the number of people per hectare in } 1885 \text {. Landownership concentration is constructed as the number of farms larger than } 100 \\
\text { ha over the total number of farms in } 1882 \text { and is standardized with zero mean and unit standard deviation. Emp. in agriculture } \\
\text { (manufacturing) denotes the percentage of people employed in agriculture (manufacturing) in } 1882 \text {. Province fixed-effects include } \\
\text { six provinces. Annexation fixed effects include eight territories. Additional controls include: an indicator for counties at the } \\
\text { border, distance to the provincial capital, and distance to Berlin. Robust standard errors are reported in parentheses. ***, **, and * } \\
\text { denote significance at } 10 \%, 5 \% \text {, and } 1 \% \text {, respectively. }\end{array}$} \\
\hline
\end{tabular}

\subsection{Robustness checks}

The rich specifications in Table 4 already provided some tests about the validity of our instrumentation. In this section we test the robustness of our main results accounting for further possible confounding variables. The estimates are shown in Table 5. 
As discussed previously, the state subsidized primary education in fiscally-challenged municipalities (Neugebauer, 1992). Relying on state grants or state funds might have decreased local spending on education. This reliance on state funding might be also related to linguistic polarization and thus partially explain our results. In column 1 of Table 5 we include log state spending on education per 1,000 children in school age (6-14). The coefficient for state spending suggests a "substitution" between state and local spending on education. This confirms that state expenditures were largely used as subsidies where local spending was insufficient.

Different linguistic groups might have different fertility levels which, in turn, could affect local educational policy. To account for differences in fertility we use the crude birth rate constructed as the ratio of children born over 10,000 people in 1885 . This variable is included in column 2. There is no significant relationship between our fertility measure and local spending on education and the inclusion of this variable does not affect the effect of linguistic polarization.

The size of the bureaucracy could have an impact on the enforcement of rules and thus also on local spending on education. The size of the bureaucracy, in turns, could also be related to different levels of linguistic polarization. In column 3 we include the share of people employed in the public administration (including the military) as reported in the occupational census in 1882 . We find that the size of the bureaucracy is positively and significantly associated with local spending on education, supporting our line of argumentation that a larger bureaucracy enforces higher levels of local spending on primary education.

The Prussian state also aimed at monitoring primary schools by replacing clerical school inspectors with secular ones who were required to report directly to the Prussian authorities in Berlin (Lamberti, 1989). One could argue that a higher share of secular school inspectors increased local school spending as the inspectors would report to the Prussian state authorities on deficiencies in both personnel and buildings, thereby putting pressure on the municipalities to invest in their school systems. Using information from the Prussian Zentralblatt, a monthly publication of the Prussian Ministry of Ecclesiastical and Education Affairs, we have been able to construct the share of central school inspectors over all school inspectors in 1886. By including this variable in the regression (column 4) our main result does not change. When controlling for the number of inspectors per school the results are also virtually unchanged (not shown).

The polarization index captures the extent to which a society is bipolar but it does not address the issue of the identity of the largest group. For example the counties Preußisch Stargard and Rössell have both a polarization index equal to 0.66. Yet, in the first county the share of 
Table 5: Linguistic polarization and local spending on education - robustness checks

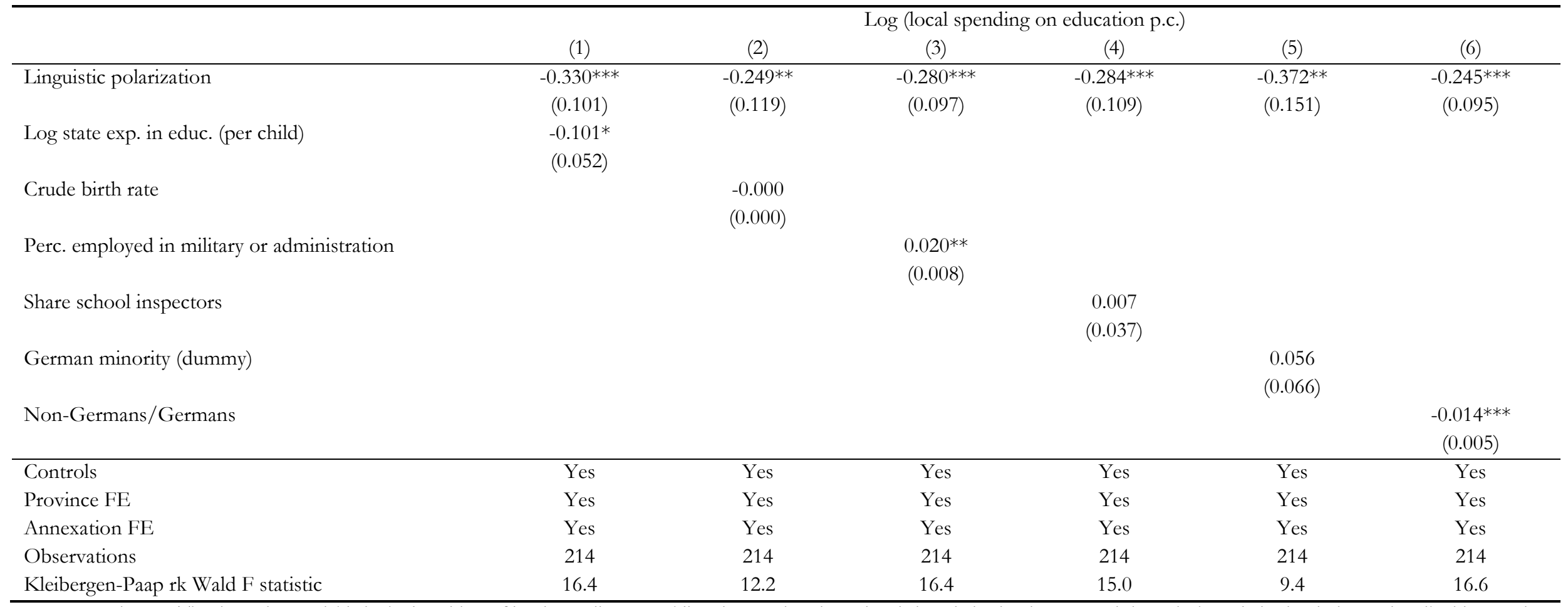

Note: IV estimates. The dependent variable is the logarithm of local spending on public primary education. Linguistic polarization is measured through the polarization index as described in equation

(1) and is based on six linguistic groups as reported in the education census in 1886: German, Polish, Lithuanian, Masurian, Slavic, and "other" language. Log state exp. in educ. (per child) measures the level of state funding on education. The crude birth rate is the total number of births over the total population in 1885. The percentage of people employed in administration measures the number of people employed in administration and military over the total population in 1882. The share of central school inspectors denotes the number of central school inspectors over total school inspectors. German minority is a dummy variable taking the value 1 if the share of German-speaking people is below 50 percent. The variable non-Germans/Germans is the ratio of the number of non-German speaking people over the number of German speaking people in 1886. Controls include: Share of Protestants, urbanization rate, population density, share of people emploved in agriculture, share of people employed in manufacturing, landownership concentration, an indicator for counties at the border, distance to the provincial capital, distance to Berlin, latitude, longitude, and latitude*longitude. Province fixed-effects include six provinces. Annexation fixed effects include eight territories. Robust standard errors are reported in parentheses. ***, ** and $*$ denote significance at $10 \%, 5 \%$ and $1 \%$, respectively. 
German speaking people is 0.21 and that of Polish-speaking people is 0.79 ; in the second county the linguistic composition is exactly the opposite. In order to test whether the identity of the largest group plays a role we include a binary variable in column 5 which takes on value 1 if the German-speaking people are the minority (27 percent of the counties). This variable is not correlated with local spending on education and the coefficient for linguistic polarization remains unaltered. ${ }^{18}$

Another way to test whether the presence of a small (large) German ruling elite opposed investments in education which otherwise would favor the large (small) non-German community is by including the ratio of the size of the respective groups. In particular in column 6 we include the ratio of the number of non-German speaking people over the number of German-speaking people. Our results indicate that the higher the ratio, i.e. the larger the number of people who do not speak German, the lower is local spending on public primary education. This result is consistent with the notion that a small local German elite blocked investments in education in counties largely populated by non-German speaking people. However our main result remains unchanged: counties with different linguistic groups of similar size tend to provide less public primary education.

\subsection{Linguistic polarization and school inputs}

We now shift our attention to the effect of linguistic polarization on schooling variables such as school density, measured as the number of schools per 1,000 children of school-age (6-14), and the number of teachers. We use our instrumental variable approach which exploits variation in linguistic polarization stemming from the conditional distance to the eastern border. Our standard set of control variables is also included. The results are presented in Table 6 .

In general we find that linguistic polarization affects negatively all school inputs with a similar magnitude. In column 1 we consider the number of schools per 1,000 children of school-age (614). The negative effect of linguistic polarization is substantial and highly significant. The size of the coefficient indicates that moving from a county with zero polarization to a county with unit polarization decreases the number of schools per 1,000 children by 1.8 units. This corresponds to about 30 percent of the mean.

\footnotetext{
18 We have also included the interaction between the dummy for German-speaking minority with polarization but we did not obtain any significant result.
} 


\begin{tabular}{|c|c|c|c|c|}
\hline & $\begin{array}{c}1) \\
\text { Number of schools } \\
\text { (per 1,000 children) }\end{array}$ & $\begin{array}{c}\text { (2) } \\
\text { Number of schools } \\
\text { w/o cities (per } 1,000 \\
\text { children) }\end{array}$ & $\begin{array}{c}\text { (3) } \\
\text { Number of teachers } \\
\text { (per } 1,000 \text { children) }\end{array}$ & $\begin{array}{c}\text { (4) } \\
\text { Teacher-student } \\
\text { ratio (per } 100 \\
\text { students) }\end{array}$ \\
\hline Linguistic polarization & $\begin{array}{c}-1.817^{* *} \\
(0.739)\end{array}$ & $\begin{array}{c}-2.435^{* * *} \\
(0.861)\end{array}$ & $\begin{array}{c}-2.711 * * * \\
(0.731)\end{array}$ & $\begin{array}{c}-0.306^{* * *} \\
(0.085)\end{array}$ \\
\hline Controls & Yes & Yes & Yes & Yes \\
\hline Province FE & Yes & Yes & Yes & Yes \\
\hline Annexation FE & Yes & Yes & Yes & Yes \\
\hline Observations & 214 & 205 & 214 & 214 \\
\hline $\begin{array}{l}\text { Kleibergen-Paap rk } \\
\text { Wald F statistic }\end{array}$ & 16.0 & 12.8 & 16.0 & 16.0 \\
\hline Mean dep. var. & 6.6 & 6.9 & 10.6 & 1.3 \\
\hline
\end{tabular}

Note: IV estimates. Linguistic polarization is measured through the polarization index as described in equation (1) and is based on six linguistic groups as reported in the education census in 1886: German, Polish, Lithuanian, Masurian, Slavic, and "other" language. Controls are: share of Protestants, urbanization rate, population density, landownership concentration, the percentage of people employed in agriculture and manufacturing, respectively, an indicator for counties at the border, distance to the provincial capital, and distance to Berlin, latitude, longitude, and their interaction. Province fixed-effects include six provinces. Annexation fixed effects include eight territories. Robust standard errors are reported in parentheses. ${ }^{* * *},{ }^{* *}$ and $*$ denote significance at $10 \%$, $5 \%$ and $1 \%$, respectively.

Fewer schools per children do not necessarily mean lower quality of schooling. Large urban schools in particular benefited from school standardization in ensuring a certain quality, schoolbased diversification and economies of scale (Kahlert, 1978). However, if we exclude the nine city-counties from our regression, the negative effect of polarization increases to 2.4 schools (column 2). Furthermore, we always control for the share of people living in urban centers which should account for the higher likelihood of larger schools in cities.

In column 3 we use the number of teachers per 1,000 children in school-age as dependent variable. Also in this case the coefficient is negative and highly significant. The size of the coefficient indicates a reduction of circa 25 percent with respect to the mean value. In column 4 we standardize the number of teachers by the number of students, computing a teacher-student ratio (per 100 students). This variable can be interpreted as a measure of the quality of teaching as it broadly captures class size. In our regression sample the average number of teachers per 100 students is 1.3, i.e. 77 students are instructed by one teacher on average. A unit change in polarization decreases the teacher-student ratio (per 100 students) by 0.3 units, which is equal to 24 percent of the mean value.

\subsection{Sorting bias: urban and rural municipalities}

There is the possibility that individuals with heterogeneous preferences sort themselves into communities that provide the typology of public goods they prefer (Tiebout, 1958). In particular, 
different linguistic groups could sort themselves into urban and rural municipalities, thus biasing our results. ${ }^{19}$

Unfortunately data on students' language directly at the municipal level for the period under investigation do not exist. However, the data from the educational census of 1886 and the financial statistics of 1883/1884 are reported separately for urban and rural municipalities, though always aggregated by county. ${ }^{20}$ In the case of urban municipalities we can look at counties with one, two, three, or more municipalities and compare the impact of linguistic polarization on local spending on education. In this way we can investigate whether and to what extent the estimates at the county level suffer from sorting or aggregation bias. ${ }^{21}$

The first thing to note is that linguistic polarization does not differ systematically between urban and rural municipalities: average polarization is 0.26 (std. dev. 0.38) in the urban sample and 0.28 (std. dev. 0.36) in the rural one. ${ }^{22}$ In the regression analysis by urban and rural municipalities only the share of Protestants and municipal tax revenues are available at that level of aggregation. Since the state subsidized primary education in fiscally-challenged municipalities, we include also the log of state expenditure in education per child in school-age. We include controls for the share of people employed in agriculture, the share of people employed in manufacturing and landownership concentration at the county-level.

We present OLS estimates by urban and rural municipalities across counties in Table $7 .^{23}$ The estimates in columns 1-5 regard urban municipalities, whereas the specification in column 6 focuses on the rural municipalities. In column 1 we use the whole sample of urban municipalities and we control for the number of municipalities. ${ }^{24}$ Note that the average number of urban

${ }^{19}$ In addition funding decisions on public primary education were taken at the municipal level whereas our data are at the county level which can include several municipalities.

20 A municipality is defined as urban when the residing population is larger than 10,000 inhabitants. The correlation between linguistic polarization in the urban municipalities of a county and total polarization in the respective county is 0.73 . The correlation of linguistic polarization in rural areas and total polarization in the relative county is 0.85 .

${ }^{21}$ In principle we could estimate a model with county-fixed effects which exploits variation between urban and rural municipalities. Yet the variation in polarization between urban and rural municipalities within a county is too low to obtain any significant result.

22 The urban sample declines from 214 to 203 observations as there are six counties that are solely constituted of rural municipalities which are Koenigsberg Landkreis, Zarbze, Niederung, Heydekrug, Karthaus and Breslau Landkreis and another five counties with missing information on the municipal taxes which are Danzig Landkreis, Pillkallen, Preussisch Stargard, Preussisch Holland and Mohrungen. The rural sample is reduced by nine counties as the city counties of Berlin, Danzig Stadtkreis, Potsdam, Breslau Stadtkreis, Stettin, Frankfurt/Oder, Posen Stadtkreis, Liegnitz Stadtkreis and Koenigsberg Stadtkreis do not comprise rural parts.

${ }^{23}$ We present OLS estimates here as IV estimates with weak instruments and small sample size are biased and highly inconsistent. However, we performed IV estimates for the full sample of urban and rural counties and the results are qualitatively similar.

${ }^{24}$ We have also run a specification with separate dummy variables for the number of counties. The results are virtually the same (available on request). 
municipalities per county is about 3. The coefficient for linguistic polarization is significantly negative and similar in magnitude to the OLS estimates in Table 2.

In column 2 we restrict the sample to 41 counties that have a single urban municipality. In this case linguistic polarization and local spending on education are observed at the "relevant" jurisdiction level for what concerns the provision of public primary education. The negative coefficient is similar in size when compared to the full urban sample and the OLS estimates in Table 2. The coefficient is not precisely estimated because of the small sample size. In column 3 we restrict the sample to counties with up to two urban municipalities and the negative coefficient for polarization becomes larger. When progressively enlarging the sample with counties with more urban municipalities (columns 4 and 5) the coefficients for polarization are again in line with the OLS estimates of Table 2.

In column 6 we report the specification for rural municipalities. Also in this case the coefficient for linguistic polarization is negative, highly significant, and similar in size to the OLS estimates as in Table 2. Since a county generally encompasses a large number of rural municipalities, data for the single rural municipalities are not provided in the original sources. Therefore we cannot perform an analysis similar to the one carried out for the urban municipalities addressing the issue of aggregation bias. However, the fact that the estimates by urban and rural municipalities are much in line with the OLS estimates in Table 2 suggest that Tiebout sorting between rural and urban municipalities is not a crucial issue. This last set of estimates suggests also that observing our variables at a higher level of jurisdiction with respect to the municipal level does not constitute a problem.

Table 7: Linguistic polarization and spending on education by number of municipalities

\begin{tabular}{|c|c|c|c|c|c|c|}
\hline & \multicolumn{5}{|c|}{ Urban } & \multirow{3}{*}{$\begin{array}{c}\text { Rural } \\
(6) \\
\text { Full sample }\end{array}$} \\
\hline & (1) & (2) & (3) & (4) & (5) & \\
\hline & Full sample & Single mun. & $<=2$ mun. & $<=3$ mun. & $<=4$ mun. & \\
\hline \multirow[t]{2}{*}{ Linguistic polarization } & $-0.177 * *$ & -0.183 & $-0.322 * * *$ & $-0.181^{*}$ & $-0.144^{*}$ & $-0.182^{* * *}$ \\
\hline & $(0.078)$ & $(0.352)$ & $(0.113)$ & $(0.097)$ & $(0.086)$ & $(0.040)$ \\
\hline \multirow[t]{2}{*}{ Number of municipalities } & 0.003 & & & & & \\
\hline & $(0.012)$ & & & & & \\
\hline Municipality level controls & Yes & Yes & Yes & Yes & Yes & Yes \\
\hline County level controls & Yes & Yes & Yes & Yes & Yes & Yes \\
\hline Observations & 203 & 41 & 86 & 134 & 161 & 205 \\
\hline R-squared & 0.26 & 0.36 & 0.30 & 0.24 & 0.23 & 0.46 \\
\hline
\end{tabular}

Note: OLS estimates. The dependent variable is the logarithm of local spending on public primary education per child of school age (6-14). Linguistic polarization is measured through the polarization index as described in equation (1) and is based on six linguistic groups as reported in the education census in 1886: German, Polish, Lithuanian, Masurian, Slavic, and "other" language. Municipality level controls are the share of Protestants and the $\log$ of municipal taxes per capita in 1883/1884. County level controls include the share of people employed in agriculture, the share of people employed in manufacturing and landownership concentration. Robust standard errors are reported in parentheses. $* * *, * *$, and $*$ denote significance at $10 \%, 5 \%$ and $1 \%$ respectively. 


\section{Linguistic polarization under centralization}

The hypothesis of this paper is that linguistic polarization in a decentralized system leads to under provision of public primary education. The cross-sectional estimates presented so far provide ample support to this hypothesis. Our interpretation of this result builds on the theoretical model proposed by Alesina et al. (1999) according to which different ethnic or linguistic groups do not want to invest local resources in the production of public goods which benefits can accrue to other groups. If this interpretation is correct, a shift to centralization in the form, for example, of state subsidies, could partially solve this coordination problem alleviating the under provision of the public good.

We can test this additional hypothesis by exploiting a reform on education spending occurred in 1888/89 which determined a partial centralization of the expenditure on primary school teachers. The objective of the law (Schulunterhaltungsgesets) was to relieve municipalities from the fiscal burden to fund primary school. This new law introduced a fixed financial support from the state for each full employed teacher which amounted to 500 Mark for the first teacher of each school, 300 Mark for every other teacher (150 Marks for every female teacher), and 100 Mark for supplementary teachers. The state contributions for each municipality were calculated on the basis of the number of teachers reported in the previous education census (i.e. in 1886 for 1891, 1891 for 1896). The same law established that school fees would be abolished and that landlords were exempted from their duty to fund schools. Since, from 1897, the state guaranteed also a uniform minimum wage for teachers which altered the allocation of state funds, we restrict our panel analysis to the years 1886, 1891, and 1896.

As a result of the policy change, state spending on primary education increased on average from 10 percent to 35 percent of the total spending between 1886 and 1891. Figure 4 shows the distributions of the share of state spending in 1886 and 1891. We can see that not only the average level of central spending increased significantly, but also the distribution is much less skewed in 1891. The shift to centralization is particularly accentuated if we consider the expenditure on teachers: the state contribution increased from 14 percent to 50 percent.

By shifting part of the expenditure on education to the central state, we expect this policy change to solve partially the coordination problem between different linguistic groups and increase the provision of public education. Therefore, we expect the linguistically polarized counties to benefit the most from this policy change. 


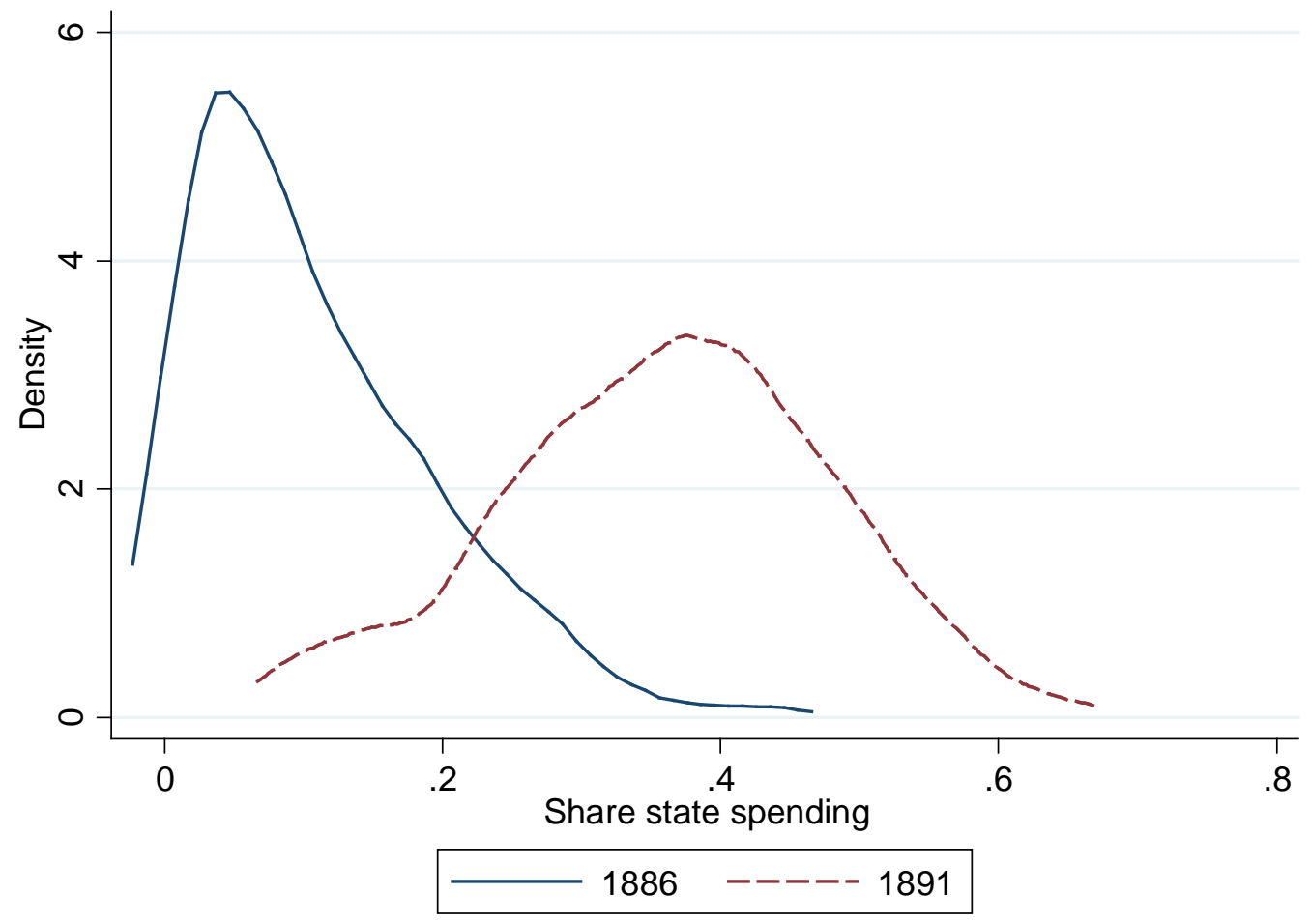

Figure 3: Density function of the share of state spending in 1886 and 1891.

We estimate a model similar in logic to a difference-in-differences approach. Including county and year fixed-effects we estimate whether total spending on education is significantly different after the reform in 1886 in highly polarized counties with respect to low polarized ones. By including county and year fixed-effects we can account for time-invariant unobserved heterogeneity across counties and common shocks, respectively. The identification relies on the assumption that there are no other changes, beyond those we have controlled for, that occurred between 1886 and 1891 which affected the education outcomes. It is also crucial that the increased state contributions were not targeted to counties with a high linguistic polarization.

The model estimated is the following:

$$
Y_{i t}=\alpha_{i}+\delta_{t}+\beta_{1} \cdot \text { polar }_{i t}+\beta_{2} \cdot \text { polar }_{i t} \cdot \text { post }_{t}+X_{i t}^{\prime} \cdot \gamma+\epsilon_{i t}
$$

where $\alpha_{i}$ and $\delta_{t}$ denote, respectively, county and year fixed-effects; polar is our variable for linguistic polarization which varies across counties and over time; ${ }^{25} X_{i t}$ is a vector of covariates which includes the share of Protestants, urbanization rate, population density, landownership concentration, share of people employed in agriculture, and the share of people employed in

\footnotetext{
${ }^{25}$ It is important to note that the time-variation of linguistic polarization is extremely low.
} 
manufacturing; $\epsilon_{i t}$ is the error term. The coefficient of interest is $\beta_{2}$ which captures the difference in outcomes for polarized counties relative to non-polarized counties after the reform.

In a more flexible approach we allow the coefficient for polarization to vary over time and estimate equation (6). In this case the coefficient $\beta_{t}$ shows for the indicated year the difference in the outcome variable between high and low polarized counties with respect to the baseline year 1886. More formally, the flexible model estimated is the following:

$$
Y_{i t}=\alpha_{i}+\delta_{t}+\sum_{t=1891}^{1896} \beta_{t} \cdot \text { polar }_{i t}+X_{i t}^{\prime} \cdot \gamma+\epsilon_{i t}
$$

As dependent variable we consider the log of total expenditure on primary education, the number of teachers per 1,000 children aged 6-14, and the teacher-student ratio. Consistently with our hypothesis we expect total spending on education and the provision of teachers to increase comparatively more in linguistically polarized counties after the reform in 1888/89.

The panel estimates are presented in Table 8. In this case we consider the whole Prussia as it increases the counterfactual group, namely the number of counties with no polarization. We will show that we obtain the same results when focusing on the East Elbian sample.

In columns 1 to 4 , we use the log of total spending on public primary education as dependent variable. In column 1 we report the estimates of equation 5 , where we estimate the impact of the reform in polarized counties. The coefficient of the interaction between linguistic polarization and the post-reform dummy is positive and significant. This lends support to our hypothesis that linguistically polarized counties benefitted the most from the shift to centralization by increasing relatively more total spending on education. In column 2 we estimate the flexible model as in equation (6). We can see that the positive effect of the reform in polarized counties persists with a similar magnitude until 1896.

In column 3 we include province-by-year fixed effects. This is to account for regulations complementary to the policy reform which varied across provinces. For instance, for the provinces of Posen and West-Prussia, beyond the contributions to cover the costs of teachers, the central state retained also the right to decide about the number and quality of teachers. Furthermore, the state granted also subsidies for the maintenance and construction of new schools. The inclusion of province by year fixed effects does not affect our coefficients of interest which remain significant and similar in size. The same applies when estimating the model only for counties east of the river Elbe (column 4). 
In columns 5-8 we use the number of teachers per 1,000 children of school age (6-14) as dependent variable. The estimates show a similar pattern: after the reform the provision of teachers increases relatively more in polarized counties. However, the flexible estimates seem to suggest that the impact of the reform on the number of teachers in polarized counties diminishes between 1891 and 1896 .

Finally in columns 9-12 we consider the teacher-student ratio (per 100 students) as dependent variable to account for differences in enrollment rates. Also in this case, in the census year after the reform the initial gap in teacher-student ratio is completely closed in polarized counties. The positive effect of the reform diminishes, however, in 1896.

The results of the panel approach thus support our hypothesis that a change to centralization, by shifting part of the costs of education from the local to the central level, can improve the under provision of public goods in linguistically polarized counties. 
Table 8: Linguistic polarization, total spending on education, and the number of teachers under centralization

\begin{tabular}{|c|c|c|c|c|c|c|c|c|c|c|c|c|}
\hline & \multicolumn{4}{|c|}{ Log (total spending on education) } & \multicolumn{4}{|c|}{ Teachers (per 1,000 children) } & \multicolumn{4}{|c|}{ Teacher-student ratio (* 100 students) } \\
\hline & (1) & (2) & (3) & $(4)$ & (5) & (6) & (7) & (8) & (9) & $(10)$ & (11) & $(12)$ \\
\hline & & & & East Elbe & & & & East Elbe & & & & East Elbe \\
\hline \multirow[t]{2}{*}{ Linguistic polarization } & 0.116 & 0.110 & 0.140 & -0.054 & -2.074 & $-2.768^{*}$ & -2.345 & -1.206 & -0.216 & $-0.292 * *$ & $-0.282^{* *}$ & -0.152 \\
\hline & $(0.184)$ & $(0.186)$ & $(0.174)$ & $(0.189)$ & $(1.480)$ & $(1.481)$ & $(1.435)$ & $(1.604)$ & $(0.136)$ & $(0.141)$ & $(0.135)$ & $(0.144)$ \\
\hline Linguistic polarization*Post & $\begin{array}{c}0.084^{* * *} \\
(0.021)\end{array}$ & & & & $\begin{array}{c}1.341 * * * \\
(0.203)\end{array}$ & & & & $\begin{array}{c}0.141^{* * *} \\
(0.026)\end{array}$ & & & \\
\hline \multirow[t]{2}{*}{ Linguistic polarization*1891 } & & $0.089 * * *$ & $0.070^{* *}$ & $0.085^{* * *}$ & & $1.976^{* * *}$ & $2.107 * * *$ & $2.374 * * *$ & & $0.210 * * *$ & $0.193^{* * *}$ & $0.219^{* * *}$ \\
\hline & & $(0.023)$ & $(0.030)$ & $(0.031)$ & & $(0.314)$ & $(0.381)$ & $(0.391)$ & & $(0.044)$ & $(0.039)$ & $(0.041)$ \\
\hline \multirow[t]{2}{*}{ Linguistic polarization*1896 } & & $0.079 * * *$ & $0.080 * * *$ & $0.097 * * *$ & & $0.749 * * *$ & $0.637 * * *$ & $0.794 * * *$ & & $0.076^{* * *}$ & $0.061 * * *$ & $0.073^{* * *}$ \\
\hline & & $(0.023)$ & $(0.028)$ & $(0.028)$ & & $(0.185)$ & $(0.220)$ & $(0.226)$ & & $(0.019)$ & $(0.022)$ & $(0.023)$ \\
\hline Controls & Yes & Yes & Yes & Yes & Yes & Yes & Yes & Yes & Yes & Yes & Yes & Yes \\
\hline County FE & Yes & Yes & Yes & Yes & Yes & Yes & Yes & Yes & Yes & Yes & Yes & Yes \\
\hline Year FE & Yes & Yes & Yes & Yes & Yes & Yes & Yes & Yes & Yes & Yes & Yes & Yes \\
\hline Province*Year FE & No & No & Yes & Yes & No & No & Yes & Yes & No & No & Yes & Yes \\
\hline Observations & 1355 & 1355 & 1355 & 642 & 1355 & 1355 & 1355 & 642 & 1356 & 1356 & 1356 & 642 \\
\hline R-squared (within) & 0.81 & 0.81 & 0.84 & 0.84 & 0.56 & 0.56 & 0.74 & 0.72 & 0.54 & 0.55 & 0.71 & 0.66 \\
\hline Mean of the dependent variable & 3.22 & 3.22 & 3.22 & 3.12 & 14.14 & 14.14 & 14.14 & 13.60 & 1.51 & 1.51 & 1.51 & 1.47 \\
\hline
\end{tabular}

Note: Panel estimates. Linguistic polarization is measured through the polarization index as described in equation (1) and is based on six linguistic groups as reported in the education census in 1886: German, Polish, Lithuanian, Masurian, Slavic, and "other" language. Post is a dummy variable for the years 1891 and 1896 after the reform. Controls are: share of Protestants, urbanization rate, population density, landownership concentration, the percentage of people employed in agriculture and manufacturing, respectively. Robust standard errors reported in parentheses are clustered at the county level. ${ }^{* *}, * *$ and $*$ denote significance at $10 \%, 5 \%$ and $1 \%$, respectively. 


\section{Conclusion}

Recent literature has shown that fiscal decentralization is positively related to education outcomes. In this study we test the hypothesis that heterogeneous preferences over the local provision of public education, in a context of strong decentralization, can lead to under provision of primary education. Nineteenth-century Prussia is an ideal laboratory to study this issue because of a highly decentralized education system and a linguistically polarized society which led to conflicting interests over the provision of primary education.

Exploiting unique county-level data on local and central expenditure on public primary education in 1886 we show that for a given level of development and municipal tax revenues, linguistically polarized counties invested fewer local resources in primary education. Consistent with the notion that public education was a contested public good between linguistic groups, we find that linguistic polarization has no bearing on local spending on transport infrastructure.

Instrumental variable estimates using distance to the eastern border, motivated by the progressive eastward annexations of Slavic populations which determined different levels of linguistic polarization, suggest a causal interpretation of our results. Consistently, we find that linguistic polarization has a negative impact also on the number of schools and teachers per children in school age.

We further test the hypothesis that centralization, by shifting part of the education costs from the local to the central level, can alleviate the under provision of education. Thus, we exploit a policy change in education funding that increased the state contributions to cover teachers' costs. By estimating a model similar to a difference-in-difference approach we show that, after the reform towards centralization, the number of teachers per child 6-14 and the teacher-student ratio increased relatively more in polarized counties.

This study presents a case under which centralization can lead to better outcomes. In a society characterized by high levels of diversity in terms of culture, ethnicity, and language, heterogeneity of preferences in the presence of strong decentralization can lead to a standstill and to a relatively lower provision of contested public goods. We show that changing the way the production of public goods is financed can partially solve coordination problems and improve the provision of contested public goods. 


\section{References}

Alesina, A., Baqir, R., \& Easterly, W. (1999). Public Goods and Ethnic Divisions. Quarterly Journal of Economics, 114(November), 1243-1284.

Alesina, A., and La Ferrara, E. (2005). Ethnic Diversity and Economic Performance. Journal of Economic Literature, 43(3), 762-800.

Alexander, M. (2008). Kleine Geschichte Polens. Stuttgart: Reclam.

Anderson, E. N. (1970). The Prussian Volksschule in the Nineteenth Century. In G. A. Ritter (Ed.), In Entstehung und Wandel der modernen Gesellschaft. Festschrift für Hans Ro-senberg zum 65. Geburststag (pp. 261-279). Berlin: Walter de Gruyter.

Barankay, I., \& Lockwood, B. (2007). Decentralization and the productive efficiency of government: Evidence from Swiss cantons. Journal of Public Economics, 91(5-6), 1197-1218.

Bardhan, P. (2002). Decentralization of Governance and Development. Journal of Economic Perspectives, 16(4), 185-205.

Becker, S. O., Cinnirella, F., Hornung, E., \& Woessmann, L. (2014). The ifo Prussian Economic History Database Francesco Cinnirella The ifo Prussian Economic History Database. Historical Methods: A Journal of Quantitative and Interdisciplinary History, 47(2), 57-66.

Becker, S. O., Hornung, E., \& Woessmann, L. (2011). Education and Catch-up in the Industrial Revolution. American Economic Journal: Macroeconomics, 3, 92-126.

Becker, S. O., and Woessmann, L. (2009). Was Weber Wrong? A Human Capital Theory of Protestant Economic History. Quarterly Journal of Economics, 124(2), 531-596.

Berger, P. (1897). Das preussische Lehrerbesoldungsgesetz vom 3. März 1897. Finanzarchiv, 14(2).

Besley, T., \& Coate, S. (2003). Centralized versus decentralized provision of local public goods: a political economy approach. Journal of Public Economics, 87(12), 2611-2637.

Chaudhary, L., Musacchio, A., Nafziger, S., \& Yan, S. (2012). Big BRICs, weak foundations: The beginning of public elementary education in Brazil, Russia, India, and China. Explorations in Economic History, 49(2), 221-240.

Chaudhary, L., \& Rubin, J. (2015). Religious Identity and the Provision of Public Goods: Evidence from the Indian Princely States. Working paper available at SSRN: http:/ / ssrn.com/abstract $=2338656$

Cinnirella, F., \& Hornung, E. (2016). Landownership Concentration and the Expansion of Education. Journal of Development Economics, 121, 135-152.

Clark, C. (2007). Iron Kingdom. The Rise and Fall of Prussia, 1600-1947. London: Penguin Books.

Collier, P., \& Hoeffler, A. (2004). Greed and grievance in civil war. Oxford Economic Papers, 56, $563-595$. 
Cvrcek, T., \& Zajicek, M. (2013). School, what is it good for? Useful Human Capital and the History of Public Education in Central Europe. NBER Working Paper No. 19690.

Dahlberg, M., Edmark, K., \& Lundqvist, H. (2012). Ethnic Diversity and Preferences for Redistribution. Journal of Political Economy, 120(1), 41-76.

Duclos, J. Y., Esteban, J., \& Ray, D. (2004). Polarization: Concepts, measurement, estimation. Econometrica, 72(6), 1737-1772.

Esteban, J., Mayoral, L., \& Ray, D. (2012). Ethnicity and Conflict: An Empirical Study. American Economic Review, 102(4), 1310-1342.

Esteban, J., \& Ray, D. (1994). On the Measurenment of Polarization. Econometrica, 62(4), 819-851. Esteban, J., \& Ray, D. (2012). Comparing Polarization Measures. In M. R. Garfinkel \& S. Skaperdas (Eds.), The Oxford Handbook of the Economics of Peace and Conflict. Oxford.

Faguet, J.-P. (2004). Does decentralization increase government responsiveness to local needs? Evidence from Bolivia. Journal of Public Economics, 88(3-4), 867-893.

Fearon, J. D., \& Laitin, D. D. (2003). Ethnicity, Insurgency and Civil War. American Political Science Review, 97(1), 75-90.

Galiani, S., Gertler, P., \& Schargrodsky, E. (2008). School decentralization: Helping the good get better, but leaving the poor behind. Journal of Public Economics, 92(10-11), 2106-2120.

Gallego, F. (2010). Historical Origins of Schooling: The Role of Democracy and Political Decentralization. Review of Economics and Statistics, 92(2), 228-243.

Gerdes, C. (2011). The Impact of Immigration on the Size of Government: Empirical Evidence from Danish Municipalities. Scandinavian Journal of Economics, 113(1), 74-92.

Glück, H. (1979). Die preußisch-polnische Sprachenpolitik: eine Studie zur Theorie und Methodologie der Forschung über Sprachenpolitik, Sprachbewnßtsein und Sozialgeschichte am Beispiel der preußisch-deutschen Politik gegenüber der polnischen Minderheit vor 1914. Hamburg: Buske.

Go, S., \& Lindert, P. (2010). The Uneven Rise of American Public Schools to 1850. Journal of Economic History, 70(01), 1-26.

Groeben, K. van der. (1992). Provinz Westpreußen. In G. Heinrich, F.-W. Henning, \& K. G. A. Jeserich (Eds.), Verwaltungsgeschichte Ostdeutschlands 1815-1945. Organisation - Aufgaben Leistungen der Verwaltung (pp. 261-348). Stuttgart/Berlin/Köln: Verlag W. Kohlhammer.

Grzes, B. (1992). Die Schulprobleme der Polen in Preussen in den Jahren 1815-1871. In R. Rexheuser (Ed.), Bildung und Nationalismus. Die Schule in ethnischen Mischgebieten. (19. und 20. Jahrbundert) (pp. 439-456). Lüneburg: Institut Nordostdeutsches Kulturwerk.

Hansen, G., \& Wenning, N. (2003). Schulpolitik für andere Ethnien in Deutschland. Zwischen Autonomie und Unterdrückung. Münster/New York/München/Berlin: Waxmann. 
Hanushek, E. A., Link, S., \& Woessmann, L. (2013). Does school autonomy make sense everywhere? Panel estimates from PISA. Journal of Development Economics, 104, 212-232.

Hao, Y., \& Xue, M. M. (2015). Friends from Afar: Migration, Cultural Proximity, and Primary Schooling in the Lower Yangzi, 1850-1949. GMU Working Paper in Economics No. 15-12. Available at SSRN: http://ssrn.com/abstract $=2563609$

Heinrich, G., Henning, F.-W., \& Jeserich, K. G. A. (Eds.). (1992). Verwaltungsgeschichte Ostdeutschlands 1815-1945. Organisation - Aufgaben - Leistungen der Verwaltung. Stuttgart/Berlin/Köln: Verlag W. Kohlhammer.

Hornung, E. (2014). Immigration and the Diffusion of Technology: The Huguenot Diaspora in Prussia. American Economic Review, 104(1), 84-122.

Hühner, M. (1998). Kommunalfinanzen, Kommunalunternehmen und Kommunalpolitik im Deutschen Kaiserreich. In R. Tilly (Ed.), Münsteraner Beiträge zur Cliometrie und quantitativen Wirtschaftsgeschichte. Münster: LIT Verlag.

Kahlert, H. (1978). Prolegomena zur Geschichte der Bildungsökonomie: Bibliographie und Darstellung (18501945). Weinheim: Beltz.

Königliches Statistisches Bureau in Berlin. (1889). Das gesammte Volksschulwesen im preußischen Staate im Jahre 1886. In Preussische Statistik Vol. 101. Berlin: Verlag des Königlichen Statistischen Bureaus.

Kremer, M., Moulin, S., \& Namunyu, R. (2003). Decentralization: A Cautionary Tale (No. 10).

Kuhlemann, F.-M. (1991). Schulen, Hochschulen, Lehrer. In C. Berg (Ed.), Handbuch der deutschen Bildungsgeschichte, Band 4, 1870 - 1918: von der Reichsgründung bis zum Ende des Ersten Weltkriegs (pp. 179-370). München: Beck.

Lamberti, M. (1989). State, Society and the Elementary School in Imperial Germany. New York/Oxford: Oxford University Press.

Lindert, P. (2004). Growing Public. Social Spending and Economic Growth since the Eighteenth Century. Growing Public (Vol. 1). Cambridge, MA: Cambridge University Press.

Lundgreen, P. (1976). Educational Expansion and Economic Growth in 19th-Century Germany. A Quantitative Study. In L. Stone (Ed.), Schooling and Society. Studies in the History of Education (pp. 20-66). Baltimore.

Luttmer, E. F. P. (2001). Group Loyalty and the Taste for Redistribution. Journal of Political Economy, 109(3), 500-528.

Miguel, E., \& Gugerty, M. K. (2005). Ethnic diversity, social sanctions, and public goods in Kenya. Journal of Public Economics, 89, 2325-2368. 
Montalvo, J. G., \& Reynal-Querol, M. (2005). Ethnic diversity and economic development. Journal of Development Economics, 76, 293-323.

Neubach, H. (1992). Die Verwaltung Schlesiens zwischen 1845 und 1945. In G. Heinrich, F.-W. Henning, \& K. G. A. Jeserich (Eds.), Verwaltungsgeschichte Ostdeutschlands 1815-1945. Organisation - Aufgaben - Leistungen der Verwaltung (pp. 878-942). Stuttgart/Berlin/Köln: Verlag W. Kohlhammer.

Neugebauer, W. (1992). Das Bildungswesen in Preußen seit der Mitte des 17. Jahrhunderts. In O. Büsch (Ed.), Handbuch der Preußischen Geschichte, Band II, Das 19. Jabrbundert und Große Themen der Geschichte Preußens (pp. 605-789). Berlin/New York: Walter de Gruyter.

Oates, W. E. (1972). Fiscal Federalism. New York: Harcourt Brace.

Oates, W. E. (1999). An Essay on Fiscal Federalism. Journal of Economic Literature, 37(3), 1120 1149 .

Ottaviano, G., \& Peri, G. (2005). Cities and cultures. Journal of Urban Economics, 58(May), 304-337.

Ottaviano, G., \& Peri, G. (2006). The economic value of cultural diversity: Evidence from US cities. Journal of Economic Geography, 6(1), 9-44.

Peri, G. (2012). The Effect Of Immigration On Productivity: Evidence From U.S. States. Review of Economics and Statistics, 94(1), 348-358.

Stichnoth, H. \& Van der Straeten, K. (2011). Ethnic Diversity, Public Speding, and Individual Support for the Welfare State: A Review of the Empirical Literature. Journal of Economic Surveys, 27(2), 364-389.

Suesse, M., \& Wolf, N. (2014). On the Economic Origins of Segregation and Nationalism: Evidence from Germany, mimeo.

Swee, E. L. (2015). Together or separate? Post-conflict partition, ethnic homogeneization, and the provision of public schooling. Journal of Public Economics, 128: 1-15.

Tiebout, C. (1958). A Pure Theory of Local Expenditures. Journal of Political Economy, LXIV, 415424.

Unruh, G.-C. von. (1992). Provinz (Großherzogtum) Posen. In G. Heinrich, F.-W. Henning, \& K. G. A. Jeserich (Eds.), Verwaltungsgeschichte Ostdeutschlands 1815-1945. Organisation - Aufgaben - Leistungen der Verwaltung (pp. 366-474). Stuttgart/Berlin/Köln: Verlag W. Kohlhammer.

Vigdor, J. L. (2002). Interpreting ethnic fragmentation effects. Economics Letters, 75(2), 271-276.

Vigdor, J. L. (2004). Community Composition and Collective Action: Analyzing Initial Mail Response to the 2000 Census. Review of Economics and Statistics, 86(1), 303-312.

Willis, E., Garman, C. C. B., \& Haggard, S. (1999). The Politics of Decentralization in Latin America. Latin American Research Review, 34(1), 7-56. 
World Bank (2004). Making Services Work for the Poor. World Bank Development Report, World Bank, Washington D.C.

Wünsch, T. (2008). Deutsche und Slawen im Mittelalter: Beziehungen zu Tschechen, Polen, Südslawen und Russen. München: Oldenbourg Verlag.

Zbroschzyk, M. (2014). Die preußische Peuplierungspolitik in den rheinischen Territorien Kleve, Geldern und Moers im Spannungsfeld von Theorie und räumlicher Umsetzung im 17. - 18. Jabrbundert.

Zernack, K. (2008). The Middle Ages. In C. W. Ingrao \& F. A. J. Szabo (Eds.), The Germans and the East (pp. 9-15). West Lafayette: Purdue University Press. 